\title{
LEVEL II SCOUR ANALYSIS FOR BRIDGE 37 (PLYMTH00080037) on TOWN HIGHWAY 8, crossing BROAD BROOK, PLYMOUTH, VERMONT
}

Open-File Report 98-556

Prepared in cooperation with

VERMONT AGENCY OF TRANSPORTATION

and

FEDERAL HIGHWAY ADMINISTRATION

U.S. Department of the Interior

U.S. Geological Survey

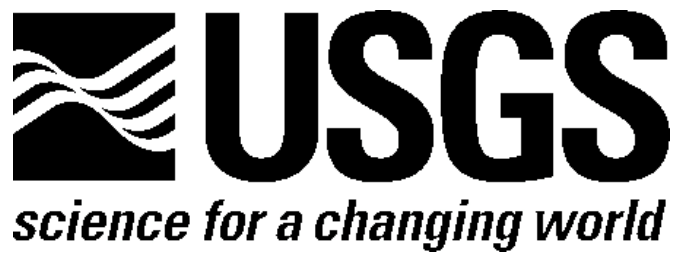




\section{LEVEL II SCOUR ANALYSIS FOR BRIDGE 37 (PLYMTH00080037) on TOWN HIGHWAY 8, crossing BROAD BROOK, PLYMOUTH, VERMONT \\ By EMILY C. WILD and LAURA MEDALIE}

U.S. Geological Survey Open-File Report 98-556

Prepared in cooperation with

VERMONT AGENCY OF TRANSPORTATION

and

FEDERAL HIGHWAY ADMINISTRATION 


\title{
U.S. DEPARTMENT OF THE INTERIOR BRUCE BABBITT, Secretary
}

\author{
U.S. GEOLOGICAL SURVEY
}

Thomas J. Casadevall, Acting Director

For additional information write to:

District Chief

U.S. Geological Survey 361 Commerce Way

Pembroke, NH 03275-3718
Copies of this report may be purchased from:

U.S. Geological Survey

Branch of Information Services

Open-File Reports Unit

Box 25286

Denver, CO 80225-0286 


\section{CONTENTS}

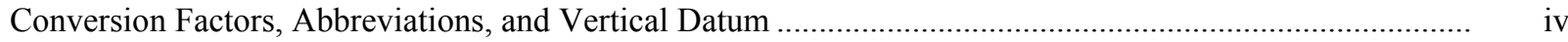

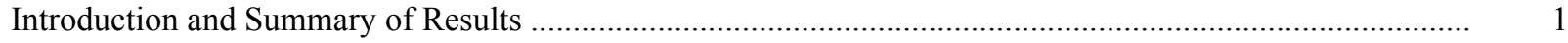

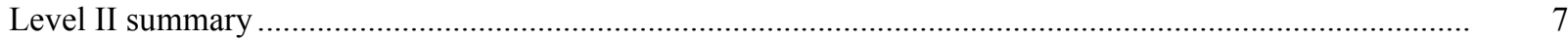

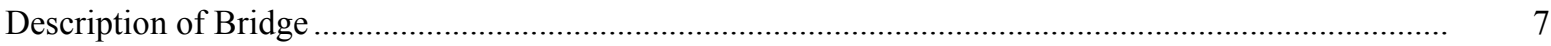

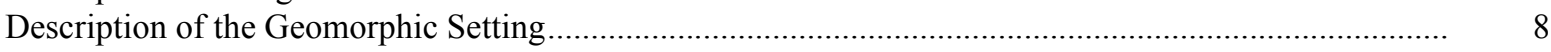

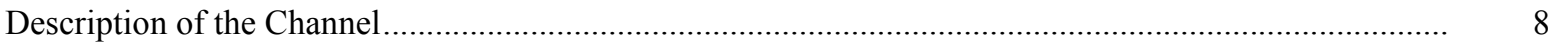

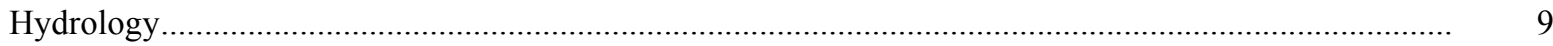

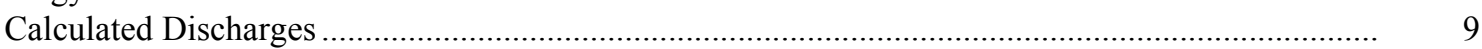

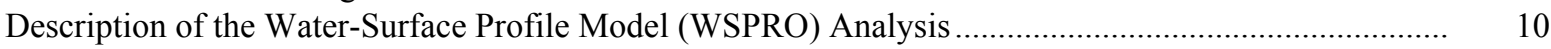

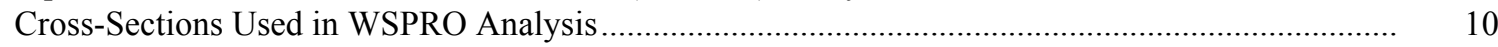

Data and Assumptions Used in WSPRO Model ........................................................................ 11

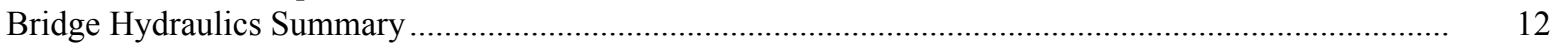

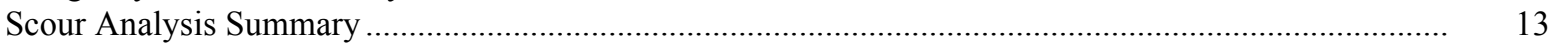

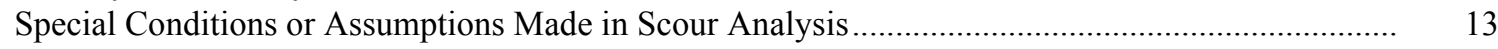

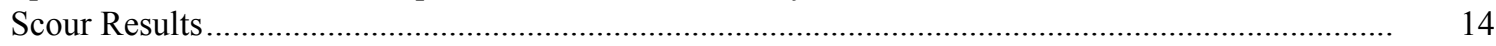

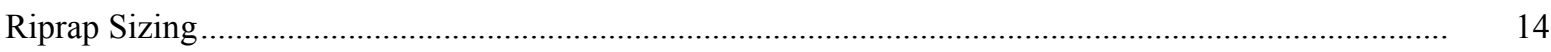

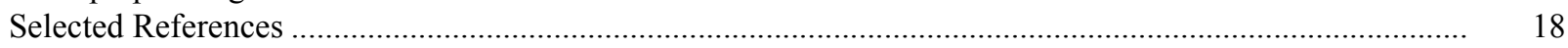

Appendices:

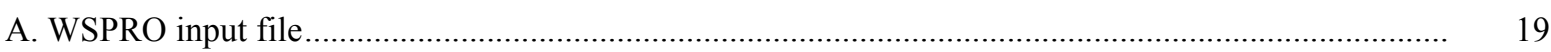

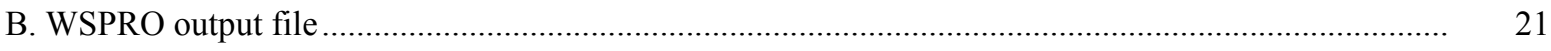

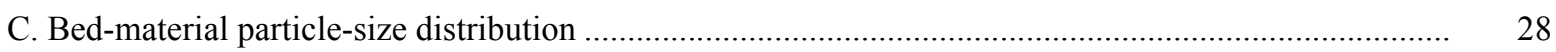

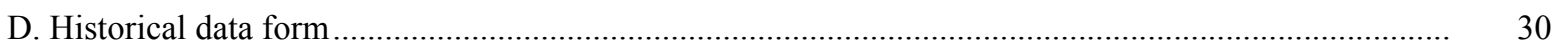

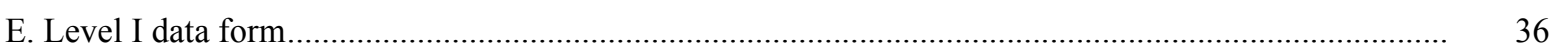

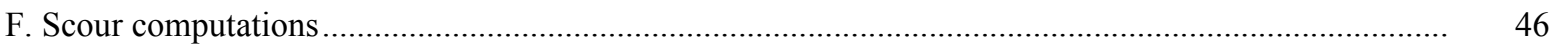

\section{FIGURES}

1. Map showing location of study area on USGS 1:24,000 scale map

2. Map showing location of study area on Vermont Agency of Transportation town highway map

3. Structure PLYMTH00080037 viewed from upstream (October 3, 1995)....

4

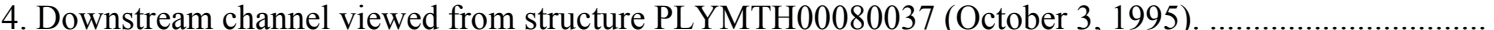

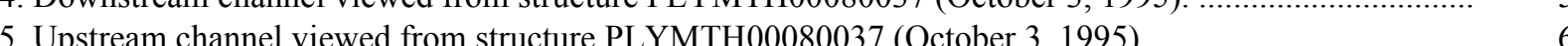

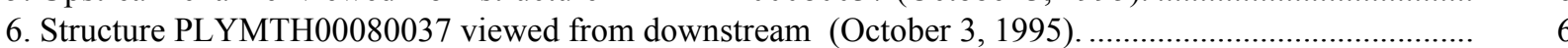

7. Water-surface profiles for the 100- and 500-year discharges at structure

PLYMTH00080037 on Town Highway 8, crossing Broad Brook,

Plymouth, Vermont.

8. Scour elevations for the 100- and 500-year discharges at structure

PLYMTH00080037 on Town Highway 8, crossing Broad Brook,

Plymouth, Vermont.

\section{TABLES}

1. Remaining footing/pile depth at abutments for the 100-year discharge at structure

PLYMTH00080037 on Town Highway 8, crossing Broad Brook,

Plymouth, Vermont.

2. Remaining footing/pile depth at abutments for the 500-year discharge at structure

PLYMTH00080037 on Town Highway 8, crossing Broad Brook,

Plymouth, Vermont. 


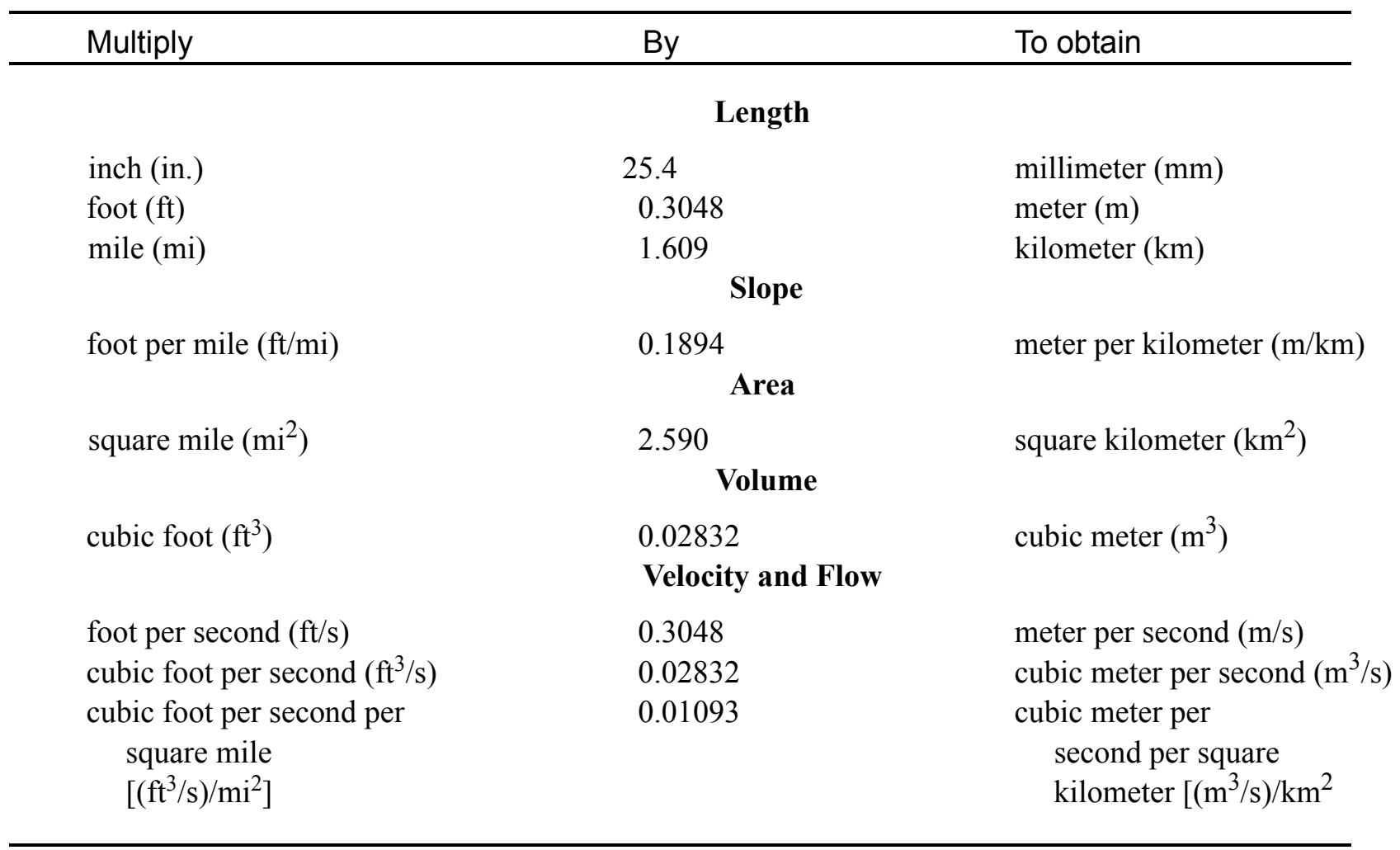

\section{OTHER ABBREVIATIONS}

$\begin{array}{lrlr}\mathrm{BF} & \text { bank full } & \text { LWW } & \text { left wingwall } \\ \mathrm{cfs} & \text { cubic feet per second } & \text { Max } & \text { maximum } \\ \mathrm{D}_{50} & \text { median diameter of bed material } & \text { MC } & \text { main channel } \\ \mathrm{DS} & \text { downstream } & \text { RAB } & \text { right abutment } \\ \mathrm{elev} & \text { elevation } & \text { RABUT } & \text { face of right abutment } \\ \mathrm{f} / \mathrm{p} & \text { flood plain } & \text { RB } & \text { right bank } \\ \mathrm{ft} & \text { square feet } & \text { ROB } & \text { right overbank } \\ \mathrm{ft} / \mathrm{ft} & \text { feet per foot } & \text { RWW } & \text { right wingwall } \\ \mathrm{FEMA} & \text { Federal Emergency Management Agency } & \text { TH } & \text { town highway } \\ \mathrm{FHWA} & \text { Federal Highway Administration } & \text { UB } & \text { under bridge } \\ \mathrm{JCT} & \text { junction } & \text { US } & \text { upstream } \\ \text { LAB } & \text { left abutment } & \text { USGS } & \text { United States Geological Survey } \\ \text { LABUT } & \text { face of left abutment } & \text { VTAOT } & \text { Vermont Agency of Transportation } \\ \text { LB } & \text { left bank } & \text { WSPRO } & \text { water-surface profile model } \\ \text { LOB } & \text { left overbank } & \text { yr } & \text { year }\end{array}$

In this report, the words "right" and "left" refer to directions that would be reported by an observer facing downstream. Sea level: In this report, "sea level" refers to the National Geodetic Vertical Datum of 1929-- a geodetic datum derived from a general adjustment of the first-order level nets of the United States and Canada, formerly called Sea Level Datum of 1929.

In the appendices, the above abbreviations may be combined. For example, USLB would represent upstream left bank. 


\title{
LEVEL II SCOUR ANALYSIS FOR BRIDGE 37 (PLYMTH00080037) ON TOWN HIGHWAY 8, CROSSING BROAD BROOK, PLYMOUTH, VERMONT
}

\author{
By Emily C. Wild and Laura Medalie
}

\section{INTRODUCTION AND SUMMARY OF RESULTS}

This report provides the results of a detailed Level II analysis of scour potential at structure PLYMTH00080037 on Town Highway 8 crossing Broad Brook, Plymouth, Vermont (figures 1-8). A Level II study is a basic engineering analysis of the site, including a quantitative analysis of stream stability and scour (FHWA, 1993). Results of a Level I scour investigation also are included in appendix $\mathrm{E}$ of this report. A Level I investigation provides a qualitative geomorphic characterization of the study site. Information on the bridge, gathered from Vermont Agency of Transportation (VTAOT) files, was compiled prior to conducting Level I and Level II analyses and is found in appendix D.

The site is in the Green Mountain section of the New England physiographic province in south-central Vermont. The 5.6- $\mathrm{mi}^{2}$ drainage area is in a predominantly rural and forested basin. In the vicinity of the study site, the surface cover is forest upstream and downstream of the bridge.

In the study area, Broad Brook has an incised, sinuous channel with a slope of approximately $0.02 \mathrm{ft} / \mathrm{ft}$, an average channel top width of $46 \mathrm{ft}$ and an average bank height of $5 \mathrm{ft}$. The channel bed material ranges from gravel to boulders with a median grain size $\left(D_{50}\right)$ of $87.5 \mathrm{~mm}(0.287 \mathrm{ft})$. The geomorphic assessment at the time of the Level I and Level II site visit on October 3, 1995, indicated that the reach was laterally unstable due to cut-banks present on the upstream left bank and the downstream left and right banks.

The Town Highway 8 crossing of Broad Brook is a 31-ft-long, one-lane bridge consisting of a 28-foot steel-stringer span (Vermont Agency of Transportation, written communication, March 22, 1995). The opening length of the structure parallel to the bridge face is $27.0 \mathrm{ft}$. The bridge is supported by vertical, concrete abutments with wingwalls. The channel is skewed approximately 15 degrees to the opening while the opening-skew-to-roadway is 15 degrees. 
During the Level I assessment, it was observed that the left abutment footing was exposed $1.25 \mathrm{ft}$ at the downstream end, and the subfooting was exposed $1 \mathrm{ft}$. Scour protection measures at the site included type-1 stone fill (less than 12 inches diameter) along the upstream right wingwall, the right abutment and the downstream right wingwall. Type-2 stone fill (less than 36 inches diameter) was along the upstream left wingwall, the upstream end of the left abutment and the downstream end of the downstream left wingwall. Additional details describing conditions at the site are included in the Level II Summary and appendices D and E.

Scour depths and recommended rock rip-rap sizes were computed using the general guidelines described in Hydraulic Engineering Circular 18 (Richardson and Davis, 1995) for the 100- and 500-year discharges. In addition, the incipient roadway-overtopping discharge was determined and analyzed as another potential worst-case scour scenario. Total scour at a highway crossing is comprised of three components: 1) long-term streambed degradation; 2) contraction scour (due to accelerated flow caused by a reduction in flow area at a bridge) and; 3) local scour (caused by accelerated flow around piers and abutments). Total scour is the sum of the three components. Equations are available to compute depths for contraction and local scour and a summary of the results of these computations follows.

Contraction scour for all modelled flows ranged from 0.0 to $0.5 \mathrm{ft}$. The worst-case contraction scour occurred at the incipient roadway-overtopping discharge, which was less than the 100-year discharge. Left abutment scour ranged from 11.1 to $12.0 \mathrm{ft}$. Right abutment scour ranged from 3.0 to $7.7 \mathrm{ft}$. The worst-case abutment scour occurred at the 500 -year discharge. Pier scour ranged from 6.2 to $7.1 \mathrm{ft}$. The worst-case pier scour also occurred at the 500-year discharge. Additional information on scour depths and depths to armoring are included in the section titled "Scour Results". Scoured-streambed elevations, based on the calculated scour depths, are presented in tables 1 and 2. A cross-section of the scour computed at the bridge is presented in figure 8. Scour depths were calculated assuming an infinite depth of erosive material and a homogeneous particle-size distribution.

It is generally accepted that the Froehlich equation (abutment scour) gives "excessively conservative estimates of scour depths" (Richardson and Davis, 1995, p. 46). Usually, computed scour depths are evaluated in combination with other information including (but not limited to) historical performance during flood events, the geomorphic stability assessment, existing scour protection measures, and the results of the hydraulic analyses. Therefore, scour depths adopted by VTAOT may differ from the computed values documented herein. 


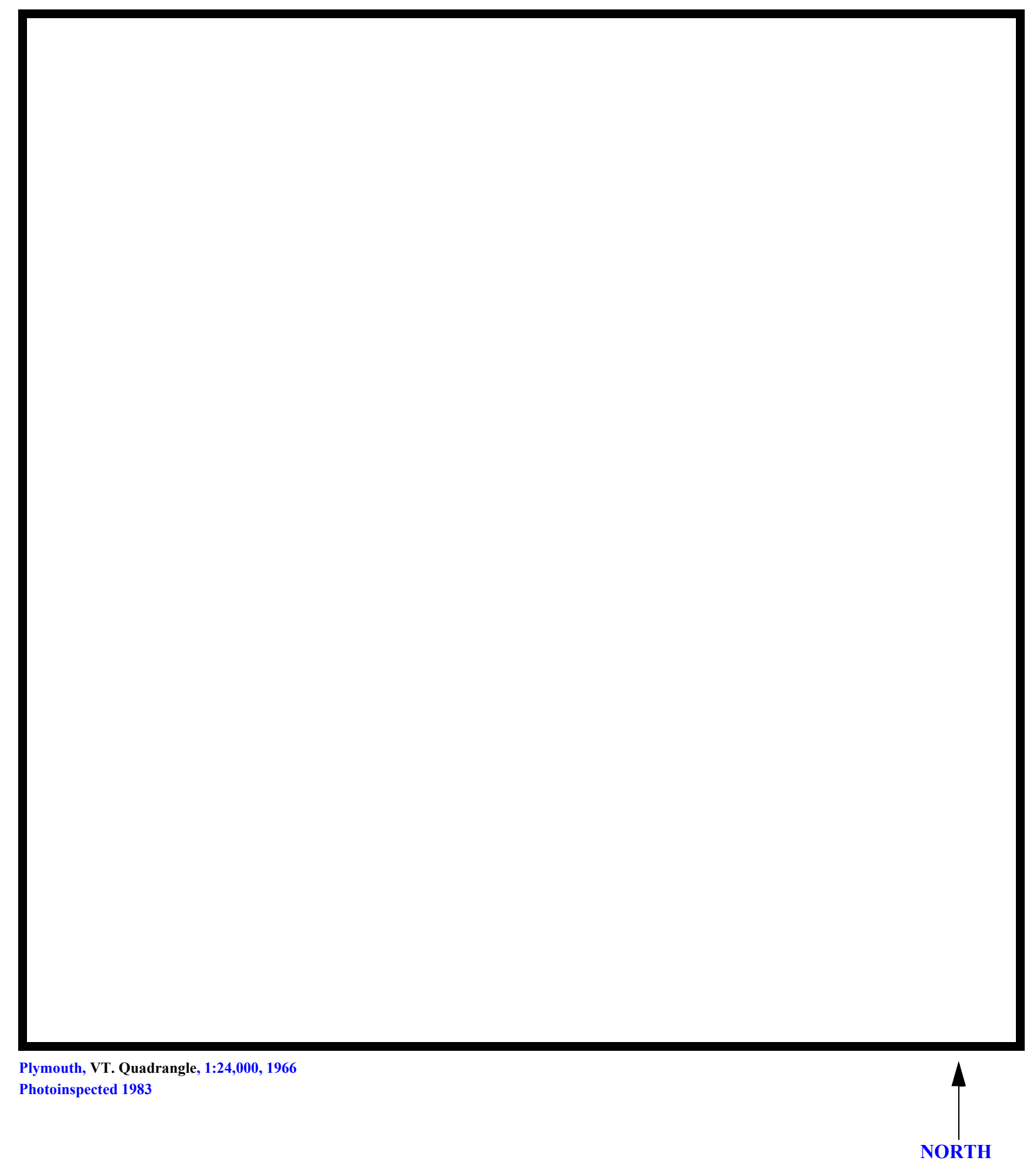

Figure 1. Location of study area on USGS 1:24,000 scale map. 
Figure 2. Location of study area on Vermont Agency of Transportation town highway map. 

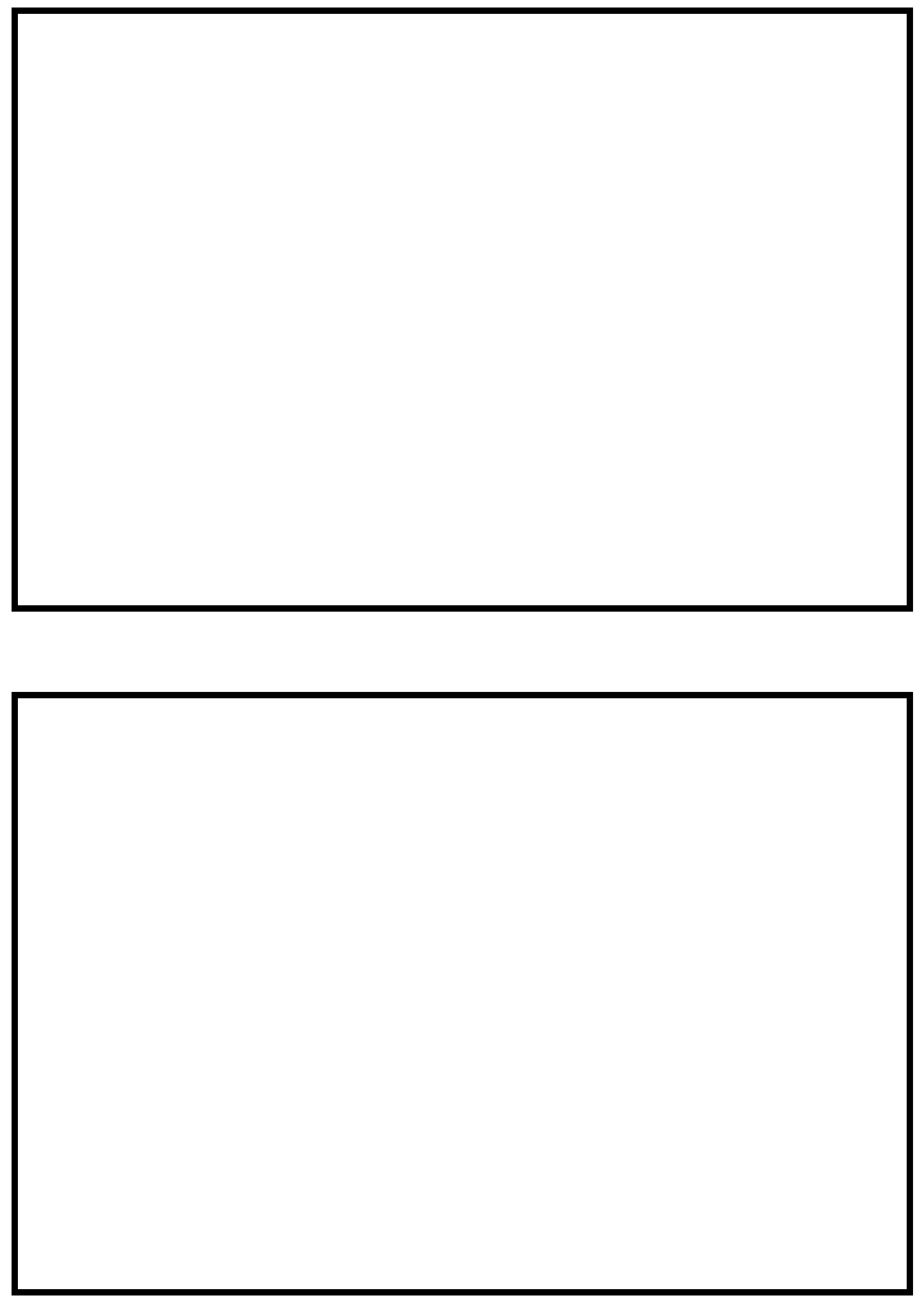

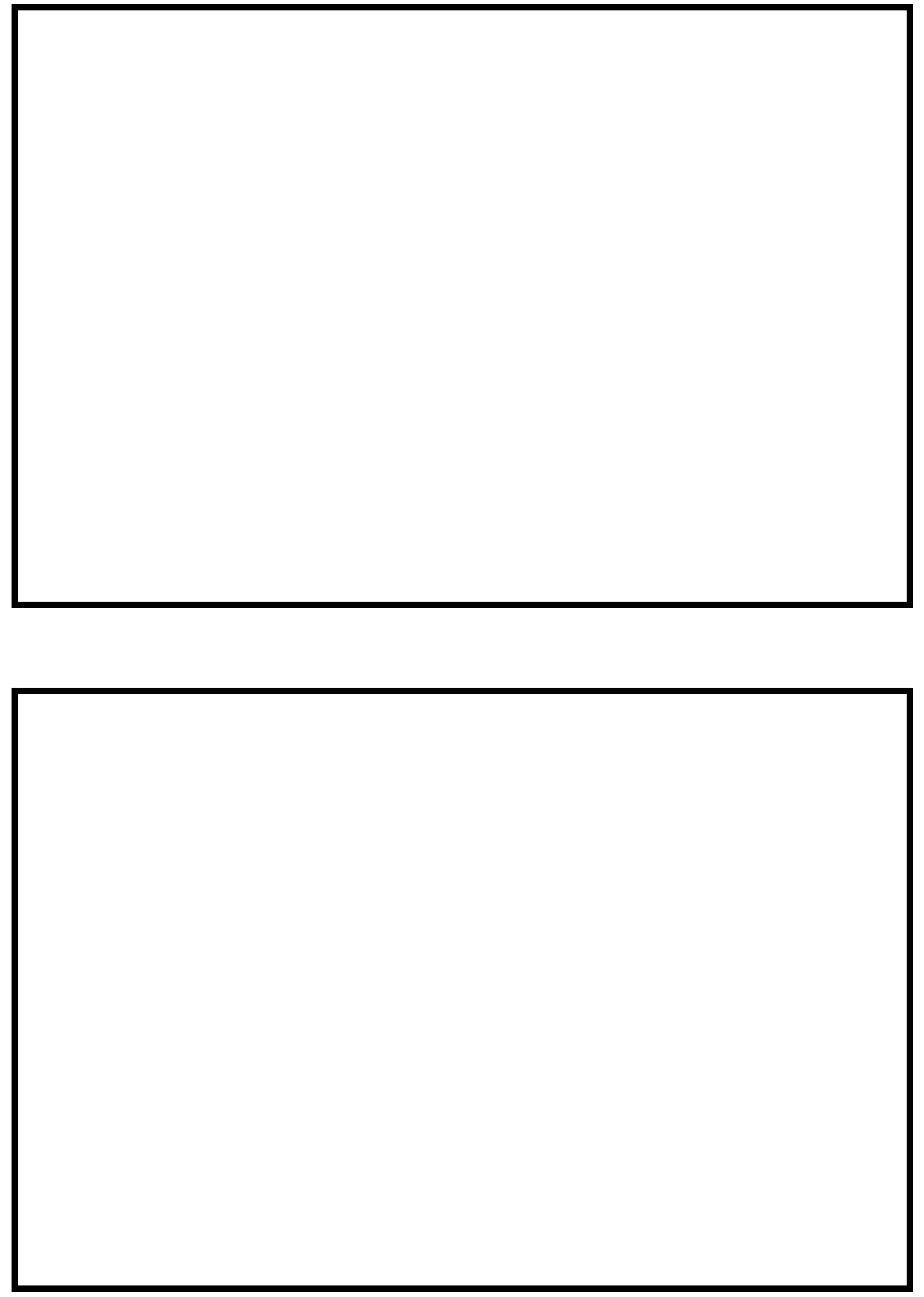


\section{LEVEL II SUMMARY}

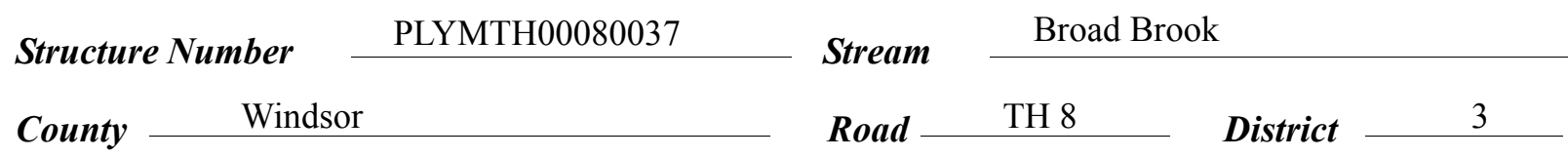

\section{Description of Bridge}

Bridge length $\frac{31}{2} \boldsymbol{f t} \quad$ Bridge width $\frac{12.8}{f t}$ Max span length $\stackrel{28}{ } \boldsymbol{f t}$ Alignment of bridge to road (on curve or straight)

\section{Abutment type} Vertical, concrete

Stone fill on abutment?

$$
\text { Yes }
$$

\section{Embankment type}

Curve

Drto af incnortion Type-1, along the upstream right wingwall, the right abutment and the

Dacauintinu af atans fill downstream right wingwall. Type-2, along the upstream left wingwall, the upstream end of the left abutment and the downstream end of the downstream left wingwall.

Abutments and wingwalls are concrete. The left abutment footing was exposed $1.25 \mathrm{ft}$ and the subfooting was exposed $1 \mathrm{ft}$ at the downstream end during the site visit.

$$
\text { Yes }
$$

Is bridge skewed to flood flow according to No ' survey?

Angle

Debris accumulation on bridge at time of Level I or Level II site visit:

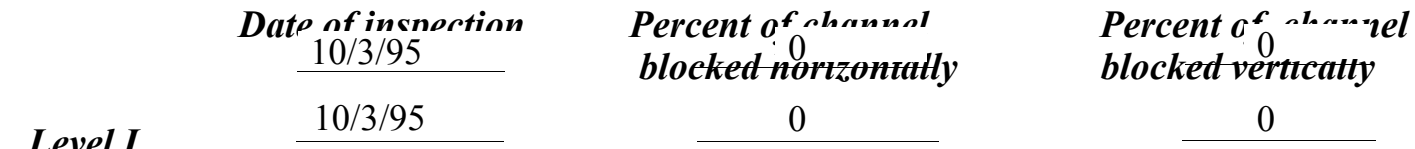

Level I

High. There is some debris in the channel at the bridge.

Level II

Potential for debris

There is a bent-type pier made of wood, located approximately in the center of the channel, as Doscriho anv, foaturos noar ar at tho hridos that mav, affoct flou, (includo ahsorvation dato) observed on 10/3/95. 


\section{Description of the Geomorphic Setting}

General topography The channel is located within a narrow flood plain with steep valley walls on both sides.

Geomorphic conditions at bridge site: downstream (DS), upstream (US)

Date of inspection $\quad 10 / 3 / 95$

DS left: $\quad$ Steep channel bank to a narrow flood plain and a steep valley wall

DS right: $\quad$ Narrow flood plain to a steep valley wall

US left: $\quad$ Steep channel bank to a moderately sloped overbank

US right: $\quad$ Narrow flood plain to a steep valley wall

\section{Description of the Channel}

\begin{tabular}{|c|c|c|c|}
\hline \multirow[b]{2}{*}{ Average top width } & 46 & \multirow[b]{2}{*}{ Average depth } & \multirow[b]{2}{*}{ Sand and Boulders } \\
\hline & Gravel $^{\boldsymbol{f t}}$ and Cobbles & & \\
\hline Predominant & & Bank material & Sinuous and laterally \\
\hline
\end{tabular}

unstable with non-alluvial channel boundäries and wide point bär."

$10 / 3 / 95$

Vegetative co ${ }^{1}$ Trees, brush and Töwn Highway 8

DS left: $\quad$ Trees and brush

DS right: $\quad$ Trees and brush

US left: $\quad$ Trees, brush and Town Highway 8

US right: $\quad$ No

Do banks appear stable? There are cut-banks, on the left and right banks and on the downstream date of observatton.

None, 10/3/95.

Describe any obstructions in channel and date of observation. 


\title{
Hydrology
}

Drainage area $\quad 5.6 \quad \mathbf{m i}^{2}$

Percentage of drainage area in physiographic provinces: (approximate)

Physiographic province/section

New England/Green Mountain
Percent of drainage area 100

\begin{abstract}
Is drainage area considered rural or urban?
Rural urbanization: None

Describe any significant
\end{abstract}

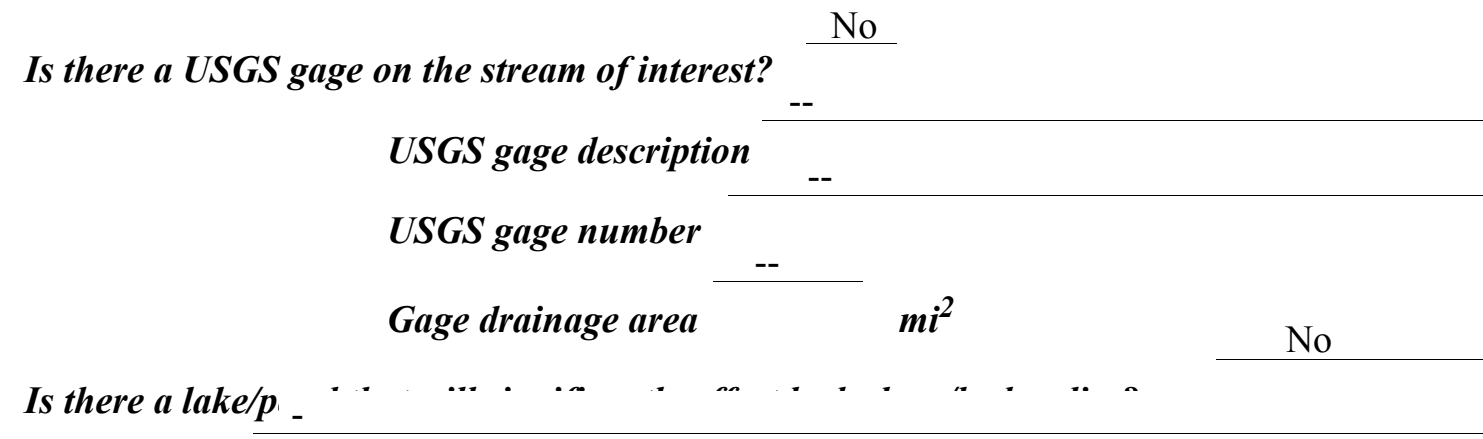

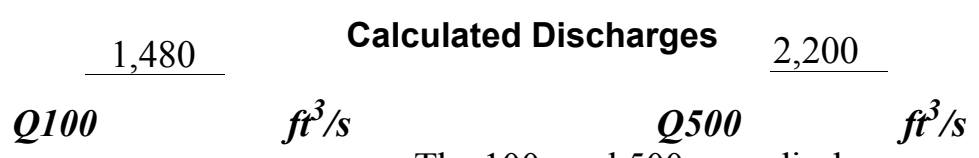

The 100- and 500-year discharges are based on a

drainage area relationship [(5.6/6.2)exp 0.67] with flood frequency estimates available from the VTAOT database (written communication, May 1995) for bridge number 38 in Plymouth. Bridge number 38 crosses the Broad Brook downstream of this site and has a drainage area above of 6.2 square miles. These area adjusted values were within a range defined by flood frequency curves derived from several empirical methods (Benson, 1962; Johnson and Tasker, 1974; FHWA, 1983; Potter, 1957a\&b; Talbot, 1887). Each curve was extended graphically to the 500-year event. 


\section{Description of the Water-Surface Profile Model (WSPRO) Analysis}

Datum for WSPRO analysis (USGS survey, sea level, VTAOT plans)

USGS survey

Datum tie between USGS survey and VTAOT plans

None

Description of reference marks used to determine USGS datum. $\quad$ RM1 is a chiseled X on

top of a boulder on the downstream right overbank, $20 \mathrm{ft}$ from the right abutment (elev. 500.57

$\mathrm{ft}$, arbitrary survey datum). RM2 is a chiseled X on top of the upstream end of the upstream left

wingwall (elev. $498.73 \mathrm{ft}$, arbitrary survey datum).

\section{Cross-Sections Used in WSPRO Analysis}

\begin{tabular}{cccl}
\hline${ }^{1}$ Cross-section & $\begin{array}{c}\text { Section } \\
\text { Reference } \\
\text { Distance } \\
\text { (SRD) } \text { in feet }\end{array}$ & $\begin{array}{c}\text { 2 Cross-section } \\
\text { development }\end{array}$ & \multicolumn{1}{c}{ Comments } \\
\hline EXIT1 & -33 & 1 & Exit section \\
FULLV & 0 & 2 & $\begin{array}{l}\text { Downstream Full-valley } \\
\text { section (Templated from } \\
\text { EXIT1) }\end{array}$ \\
BRIDG & 0 & 1 & $\begin{array}{l}\text { Bridge section } \\
\text { Road Grade section }\end{array}$ \\
RDWAY & 8 & 1 & $\begin{array}{l}\text { Modelled Approach sec- } \\
\text { tion (Templated from } \\
\text { APTEM) } \\
\text { APPR1 }\end{array}$ \\
APTEM & 42 & 2 & $\begin{array}{l}\text { Approach section as sur- } \\
\text { veyed (Used as a tem- } \\
\text { plate) }\end{array}$ \\
\hline
\end{tabular}

${ }^{1}$ For location of cross-sections see plan-view sketch included with Level I field form, Appendix E.

For more detail on how cross-sections were developed see WSPRO input file. 


\section{Data and Assumptions Used in WSPRO Model}

Hydraulic analyses of the reach were done by use of the Federal Highway Administration's WSPRO step-backwater computer program (Shearman and others, 1986, and Shearman, 1990). The analyses reported herein reflect conditions existing at the site at the time of the study. Furthermore, in the development of the model it was necessary to assume no accumulation of debris or ice at the site. Results of the hydraulic model are presented in the Bridge Hydraulic Summary, appendix B, and figure 7.

Channel roughness factors (Manning's " $n$ ") used in the hydraulic model were estimated using field inspections at each cross section following the general guidelines described by Arcement and Schneider (1989). Final adjustments to the values were made during the modelling of the reach. Channel " $n$ " values for the reach ranged from 0.050 to 0.055 , and overbank " $n$ " values ranged from 0.055 to 0.065 .

Normal depth at the exit section (EXIT1) was assumed as the starting water surface. This depth was computed by use of the slope-conveyance method outlined in the user's manual for WSPRO (Shearman, 1990). The slope used was $0.0214 \mathrm{ft} / \mathrm{ft}$, which was estimated from the appropriate topographic map (U.S. Geological Survey, 1966).

The surveyed approach section (APTEM) was moved along the approach channel slope $(0.0066 \mathrm{ft} / \mathrm{ft})$ to establish the modelled approach section (APPR1), one bridge length upstream of the upstream face as recommended by Shearman and others (1986). This location provides a consistent method for determining scour variables.

For the incipient-overtopping discharge, WSPRO assumes critical depth at the bridge section. A supercritical model was developed for this discharge. After analyzing the supercritical and subcritical profiles for the incipient-overtopping discharge, it can be determined that the water surface profile does pass through critical depth within the bridge opening. Thus, the assumption of critical depth at the bridge is a satisfactory solution. 


\section{Bridge Hydraulics Summary}

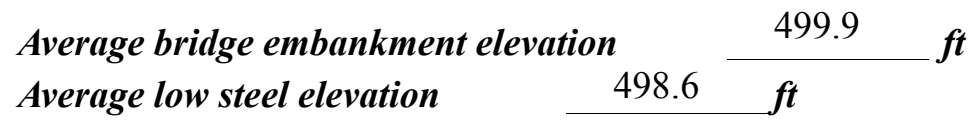

$$
\text { 100-year discharge } \quad 1,480 \quad \mathrm{ft}^{3} / \mathrm{s}
$$

Water-surface elevation in bridge opening $\quad 498.6 \quad f t$

Road overtopping? ___ Yes Discharge over road___ $163 \quad \mathrm{ft}^{3} / \mathrm{s}$

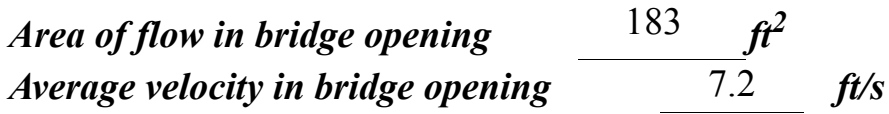

Maximum WSPRO tube velocity at bridge $11.1 \mathrm{ft} / \mathrm{s}$

Water-surface elevation at Approach section with bridge 499.7

Water-surface elevation at Approach section without bridge $\quad \overline{496.9}$

Amount of backwater caused by bridge $\quad 2.8 \quad$ it

500-year discharge $\quad 2,200 \quad \mathrm{ft}^{3} / \mathrm{s}$

Water-surface elevation in bridge opening $498.6 \mathrm{ft}$

Road overtopping? ___ Yes Discharge over road__ $663 \ldots$, is

$\begin{array}{lrr}\text { Area of flow in bridge opening } & 183 \quad \boldsymbol{f t}^{2} \\ \text { Average velocity in bridge opening } & 8.6\end{array}$

Maximum WSPRO tube velocity at bridge 13.3 , s

Water-surface elevation at Approach section with bridge 500.4

Water-surface elevation at Approach section without bridge $\quad 498.0$

Amount of backwater caused by bridge $\quad 2.4$, $t$

Incipient overtopping discharge $\quad 1,290 \mathrm{ft}^{3} / \mathrm{s}$

Water-surface elevation in bridge opening $495.7 \quad$ t

Area of flow in bridge opening $\quad 109 \quad \mathrm{ft}^{2}$

Average velocity in bridge opening $\quad 11.8 \quad \mathrm{ft} / \mathrm{s}$

Maximum WSPRO tube velocity at bridge $\quad 14.5 \mathrm{ft} / \mathrm{s}$

Water-surface elevation at Approach section with bridge

Water-surface elevation at Approach section without bridge

497.9

Amount of backwater caused by bridge $\quad 1.4$ it 


\section{Scour Analysis Summary}

\section{Special Conditions or Assumptions Made in Scour Analysis}

Scour depths were computed using the general guidelines described in Hydraulic Engineering Circular 18 (Richardson and Davis, 1995). Scour depths were calculated assuming an infinite depth of erosive material and a homogeneous particle-size distribution. The results of the scour analyses for the 100- and 500-year discharges are presented in tables 1 and 2 and the scour depths are shown graphically in figure 8 .

Contraction scour for the incipient roadway-overtopping discharge, which resulted in free-surface flow, was computed by use of the Laursen clear-water contraction scour equation (Richardson and Davis, 1995, p. 32, equation 20). At this site, the 100-year and 500 -year discharges resulted in unsubmerged orifice flow. Contraction scour at bridges with orifice flow is best estimated by use of the Chang pressure-flow scour equation (oral communication, J. Sterling Jones, October 4, 1996). Thus, contraction scour for the 100 -year and 500-year discharges was computed by use of the Chang equation (Richardson and Davis, 1995, p. 145-146). The streambed armoring depths computed suggest that armoring will not limit the depth of contraction scour.

For comparison, contraction scour for the discharges resulting in orifice flow was computed by use of the Laursen clear-water contraction scour equation and the Umbrell pressure-flow equation (Richardson and Davis, 1995, p. 144). Contraction scour for the 100 -year and 500-year discharges, which resulted in unsubmerged orifice flow, was also computed by substituting estimates for the depth of flow at the downstream bridge face in the contraction scour equations. Results with respect to these substitutions also are provided in appendix F.

Abutment scour was computed by use of the Froehlich equation (Richardson and Davis, 1995, p. 48, equation 28). Variables for the Froehlich equation include the Froude number of the flow approaching the embankments, the length of the embankment blocking flow, and the depth of flow approaching the embankment less any roadway overtopping.

The length to depth ratio of the embankment blocking flow exceeded 25 for the right abutment for each modeled discharge. Although the HIRE equation (Richardson and others, 1993 , p. 50, equation 25) generally is applicable when this ratio exceeds 25 , the results from the HIRE equation were not used. Hydraulic Engineering Circular 18 recommends that the field conditions be similar to those from which the HIRE equation was derived (Richardson and others, 1993). Since the equation was developed from U.S. Army Corps. of Engineers' data obtained for spur dikes in the Mississippi River, the HIRE equation results were not accepted for the narrow, incised, upland valley at this site.

Pier scour was computed by use of an equation developed at Colorado State University (Richardson and Davis, 1995, p. 36, eq. 21). Variables for the equation include: pier length, pier width, approach velocity and correction factors for pier shape, flow attack angle, streambed condition, streambed armoring, and average depth and maximum velocity (for the Froude number) immediately upstream of the bridge. 
Scour Results

Contraction scour:

Main channel

Live-bed scour

Clear-water scour

Depth to armoring

Left overbank

Right overbank

Local scour:

Abutment scour

Left abutment

Right abutment

Pier scour

Pier 1

Pier 2

Pier 3
12.0

7.7-

7.1
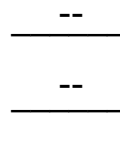

$\longrightarrow$ 500-year discharge

(Scour depths in feet)

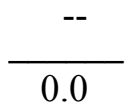

$\mathrm{N} / \mathrm{A}^{-}$

--

$--$

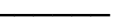

Incipient overtopping discharge 


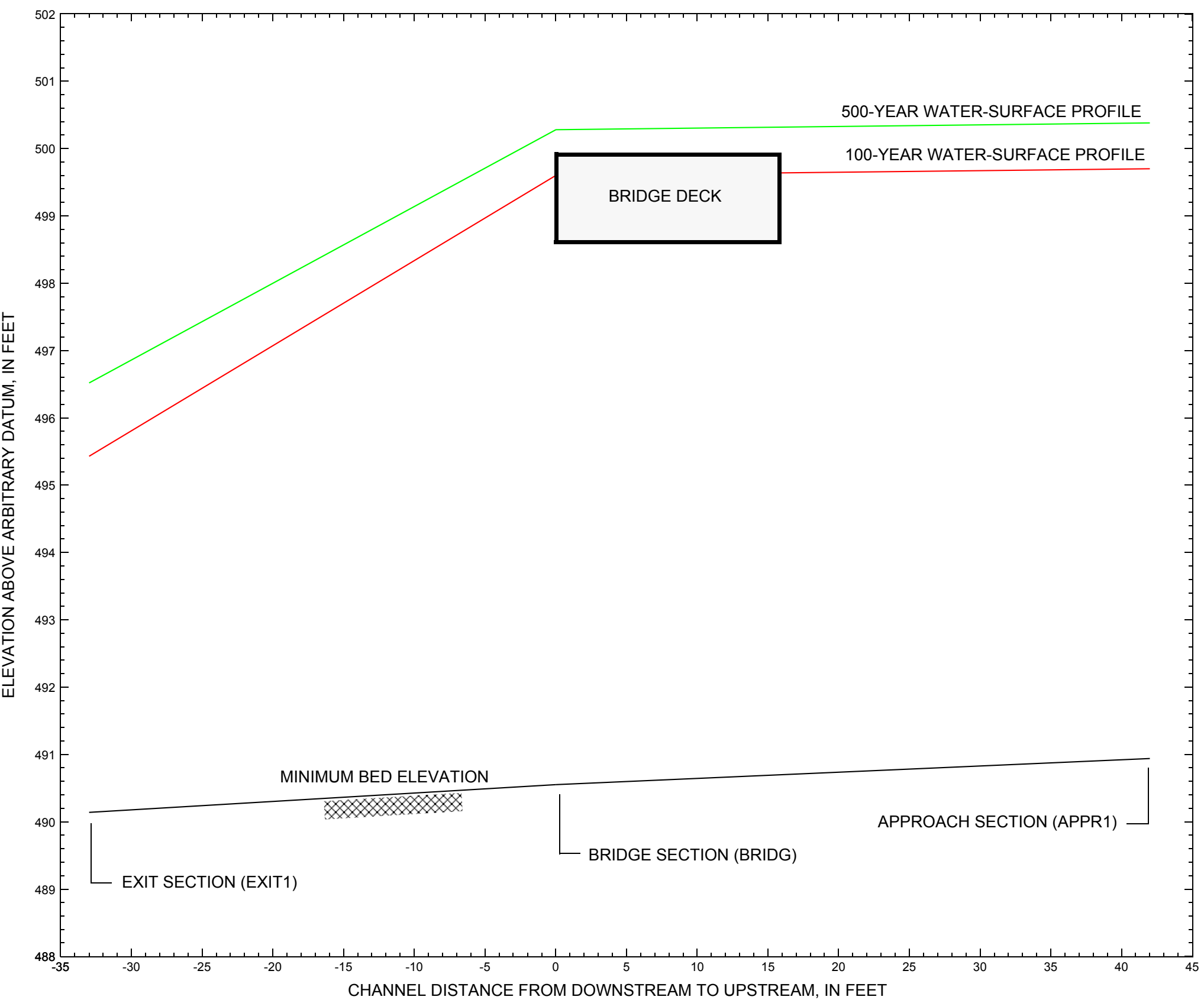

Figure 7. Water-surface profiles for the 100- and 500-year discharges at structure PLYMTH00080037 on Town Highway 8, crossing Broad Brook, Plymouth, Vermont. 


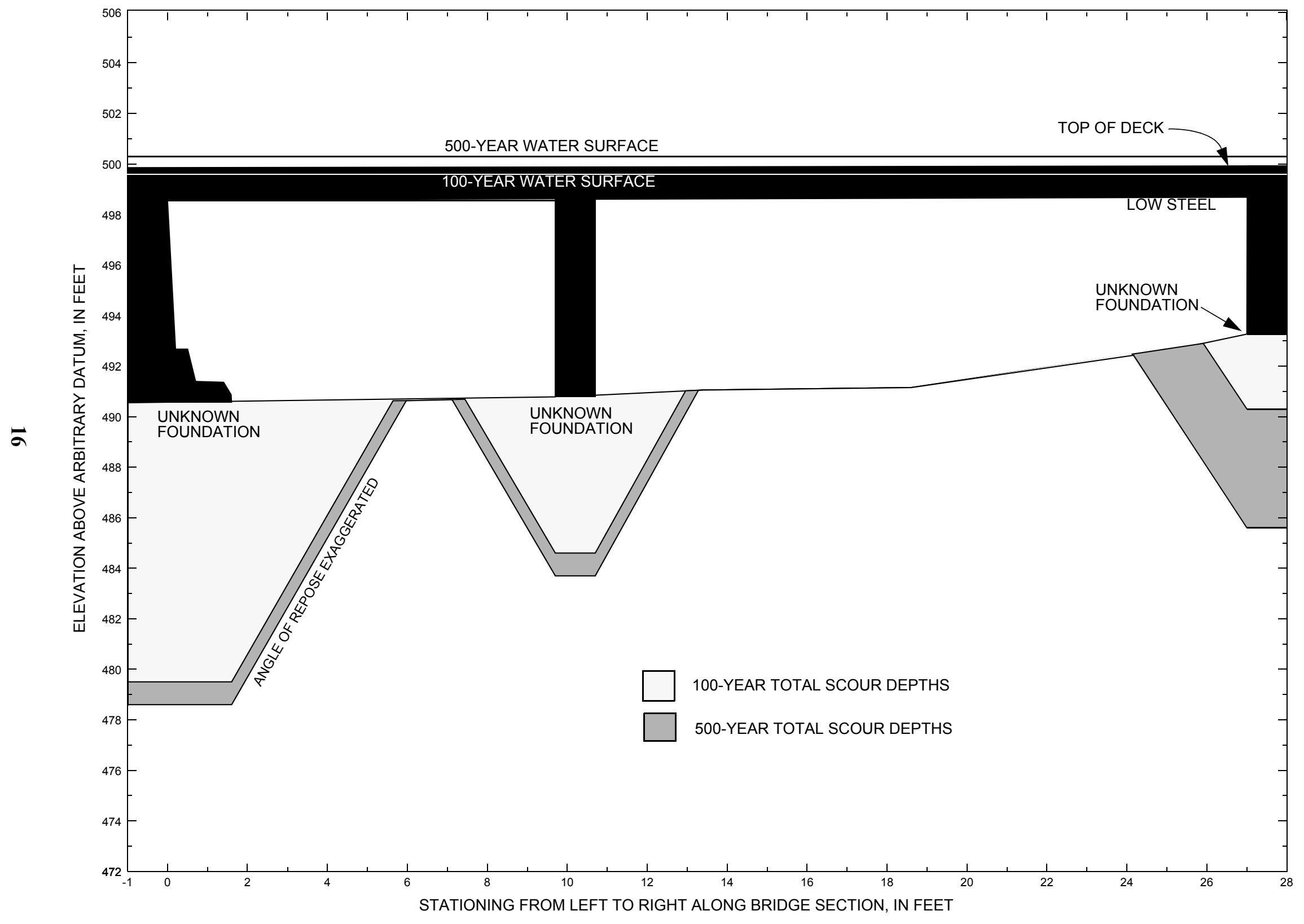

Figure 8. Scour elevations for the 100- and 500-year discharges at structure PLYMTH00080037 on Town Highway 8, crossing Broad Brook, Plymouth, Vermont. 
Table 1. Remaining footing/pile depth at abutments for the 100-year discharge at structure PLYMTH00080037 on Town Highway 8, crossing Broad Brook, Plymouth, Vermont.

[VTAOT, Vermont Agency of Transportation; --, no data]

\begin{tabular}{|c|c|c|c|c|c|c|c|c|c|c|c|}
\hline Description & Station $^{1}$ & $\begin{array}{l}\text { VTAOT } \\
\text { minimum } \\
\text { low-chord } \\
\text { elevation } \\
\text { (feet) }\end{array}$ & $\begin{array}{l}\text { Surveyed } \\
\text { minimum } \\
\text { low-chord } \\
\text { elevation }{ }^{2} \\
\text { (feet) }\end{array}$ & $\begin{array}{c}\text { Bottom of } \\
\text { footing/pile } \\
\text { elevation }{ }^{2} \\
\text { (feet) }\end{array}$ & $\begin{array}{c}\text { Channel } \\
\text { elevation at } \\
\text { abutment/ } \\
\text { pier }^{2} \\
\text { (feet) }\end{array}$ & $\begin{array}{l}\text { Contraction } \\
\text { scour depth } \\
\text { (feet) }\end{array}$ & $\begin{array}{l}\text { Abutment } \\
\text { scour } \\
\text { depth } \\
\text { (feet) }\end{array}$ & $\begin{array}{l}\text { Pier } \\
\text { scour } \\
\text { depth } \\
\text { (feet) }\end{array}$ & $\begin{array}{l}\text { Depth of } \\
\text { total scour } \\
\text { (feet) }\end{array}$ & $\begin{array}{c}\text { Elevation of } \\
\text { scour }^{2} \\
\text { (feet) }\end{array}$ & $\begin{array}{c}\text { Remaining } \\
\text { footing/pile } \\
\text { depth } \\
\text { (feet) }\end{array}$ \\
\hline \multicolumn{12}{|c|}{100 -year discharge is 1,480 cubic-feet per second } \\
\hline Left abutment & 0.0 & -- & 498.6 & -- & 490.6 & 0.0 & 11.1 & -- & 11.1 & 479.5 & -- \\
\hline Pier bent & 10.1 & -- & -- & -- & 490.8 & -- & -- & 6.2 & 6.2 & 484.6 & -- \\
\hline Right abutment & 27.0 & -- & 498.7 & -- & 493.3 & 0.0 & 3.0 & -- & 3.0 & 490.3 & -- \\
\hline
\end{tabular}

- 1.Measured along the face of the most constricting side of the bridge.

2.Arbitrary datum for this study.

Table 2. Remaining footing/pile depth at abutments for the 500-year discharge at structure PLYMTH00080037 on Town Highway 8, crossing Broad Brook, Plymouth, Vermont.

[VTAOT, Vermont Agency of Transportation; --, no data]

\begin{tabular}{|c|c|c|c|c|c|c|c|c|c|c|c|}
\hline Description & Station ${ }^{1}$ & $\begin{array}{l}\text { VTAOT } \\
\text { minimum } \\
\text { low-chord } \\
\text { elevation } \\
\text { (feet) }\end{array}$ & $\begin{array}{l}\text { Surveyed } \\
\text { minimum } \\
\text { low-chord } \\
\text { elevation } \\
\text { (feet) }\end{array}$ & $\begin{array}{c}\text { Bottom of } \\
\text { footing/pile } \\
\text { elevation }{ }^{2} \\
\text { (feet) }\end{array}$ & $\begin{array}{c}\text { Channel } \\
\text { elevation at } \\
\text { abutment/ } \\
\text { pier }^{2} \\
\text { (feet) }\end{array}$ & $\begin{array}{l}\text { Contraction } \\
\text { scour depth } \\
\text { (feet) }\end{array}$ & $\begin{array}{l}\text { Abutment } \\
\text { scour } \\
\text { depth } \\
\text { (feet) }\end{array}$ & $\begin{array}{l}\text { Pier } \\
\text { scour } \\
\text { depth } \\
\text { (feet) }\end{array}$ & $\begin{array}{l}\text { Depth of } \\
\text { total scour } \\
\text { (feet) }\end{array}$ & $\begin{array}{c}\text { Elevation of } \\
\text { scour }^{2} \\
\text { (feet) }\end{array}$ & $\begin{array}{l}\text { Remaining } \\
\text { footing/pile } \\
\text { depth } \\
\text { (feet) }\end{array}$ \\
\hline \multicolumn{12}{|c|}{500 -year discharge is 2,200 cubic-feet per second } \\
\hline Left abutment & 0.0 & -- & 498.6 & -- & 490.6 & 0.0 & 12.0 & -- & 12.0 & 478.6 & -- \\
\hline Pier bent & 10.1 & -- & -- & -- & 490.8 & -- & -- & 7.1 & 7.1 & 483.7 & -- \\
\hline Right abutment & 27.0 & -- & 498.7 & -- & 493.3 & 0.0 & 7.7 & -- & 7.7 & 485.6 & -- \\
\hline
\end{tabular}

1.Measured along the face of the most constricting side of the bridge.

2.Arbitrary datum for this study. 


\section{SELECTED REFERENCES}

Arcement, G.J., Jr., and Schneider, V.R., 1989, Guide for selecting Manning's roughness coefficients for natural channels and flood plains: U.S. Geological Survey Water-Supply Paper 2339, 38 p.

Barnes, H.H., Jr., 1967, Roughness characteristics of natural channels: U.S. Geological Survey Water-Supply Paper 1849,213 p.

Benson, M. A., 1962, Factors Influencing the Occurrence of Floods in a Humid Region of Diverse Terrain: U.S. Geological Survey WaterSupply Paper 1580-B, 64 p.

Brown, S.A. and Clyde, E.S., 1989, Design of riprap revetment: Federal Highway Administration Hydraulic Engineering Circular No. 11, Publication FHWA-IP-89-016, 156 p.

Federal Highway Administration, 1983, Runoff estimates for small watersheds and development of sound design: Federal Highway Administration Report FHWA-RD-77-158.

Federal Highway Administration, 1993, Stream Stability and Scour at Highway Bridges: Participant Workbook: Federal Highway Administration Report FHWA-HI-91-011.

Froehlich, D.C., 1989, Local scour at bridge abutments in Ports, M.A., ed., Hydraulic Engineering--Proceedings of the 1989 National Conference on Hydraulic Engineering: New York, American Society of Civil Engineers, p. 13-18.

Hayes, D.C.,1993, Site selection and collection of bridge-scour data in Delaware, Maryland, and Virginia: U.S. Geological Survey WaterResources Investigation Report 93-4017, 23 p.

Interagency Advisory Committee on Water Data, 1982, Guidelines for determining flood flow frequency: U.S. Geological Survey, Bulletin 17B of the Hydrology Subcommittee, 190 p.

Johnson, C.G. and Tasker, G.D.,1974, Progress report on flood magnitude and frequency of Vermont streams: U.S. Geological Survey OpenFile Report 74-130, 37 p.

Lagasse, P.F., Schall, J.D., Johnson, F., Richardson, E.V., Chang, F., 1995, Stream Stability at Highway Structures: Federal Highway Administration Hydraulic Engineering Circular No. 20, Publication FHWA-IP-90-014, 144 p.

Laursen, E.M., 1960, Scour at bridge crossings: Journal of the Hydraulics Division, American Society of Civil Engineers, v. 86, no. HY2, p. 39-53.

Potter, W. D., 1957a, Peak rates of runoff in the Adirondack, White Mountains, and Maine woods area, Bureau of Public Roads

Potter, W. D., 1957b, Peak rates of runoff in the New England Hill and Lowland area, Bureau of Public Roads

Richardson, E.V. and Davis, S.R., 1995, Evaluating scour at bridges: Federal Highway Administration Hydraulic Engineering Circular No. 18, Publication FHWA-IP-90-017, 204 p.

Richardson, E.V., Simons, D.B., and Julien, P.Y., 1990, Highways in the river environment: Federal Highway Administration Publication FHWA-HI-90-016.

Ritter, D.F., 1984, Process Geomorphology: W.C. Brown Co., Debuque, Iowa, 603 p.

Shearman, J.O., 1990, User's manual for WSPRO--a computer model for water surface profile computations: Federal Highway Administration Publication FHWA-IP-89-027, 187 p.

Shearman, J.O., Kirby, W.H., Schneider, V.R., and Flippo, H.N., 1986, Bridge waterways analysis model; research report: Federal Highway Administration Publication FHWA-RD-86-108, 112 p.

Talbot, A.N., 1887, The determination of water-way for bridges and culverts.

U.S. Geological Survey, 1966, Plymouth, Vermont 7.5 Minute Series quadrangle map: U.S. Geological Survey Topographic Maps, Photoinspected 1983, Scale 1:24,000. 


\section{APPENDIX A: \\ WSPRO INPUT FILE}




\section{WSPRO INPUT FILE}

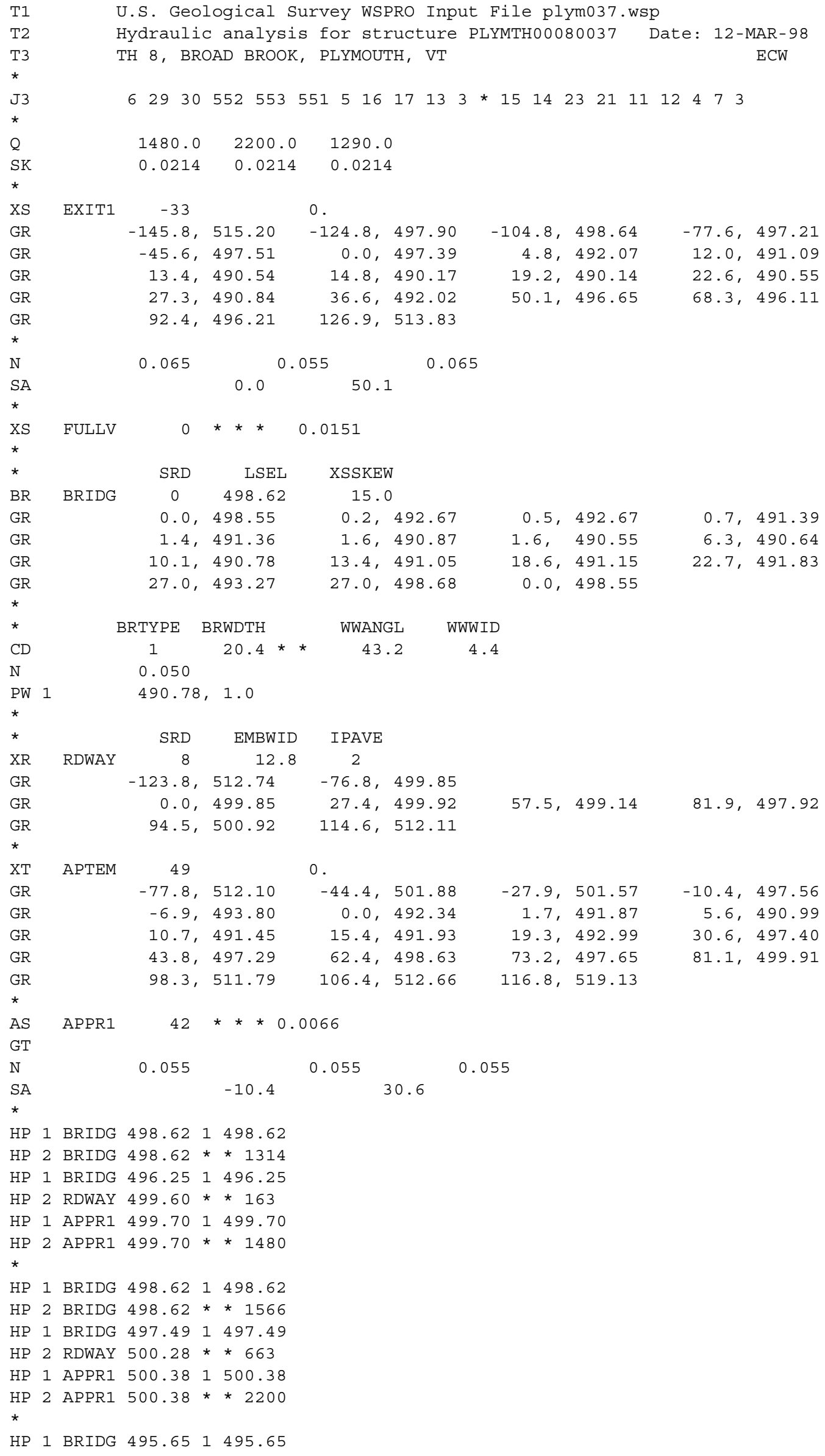




\section{APPENDIX B: \\ WSPRO OUTPUT FILE}




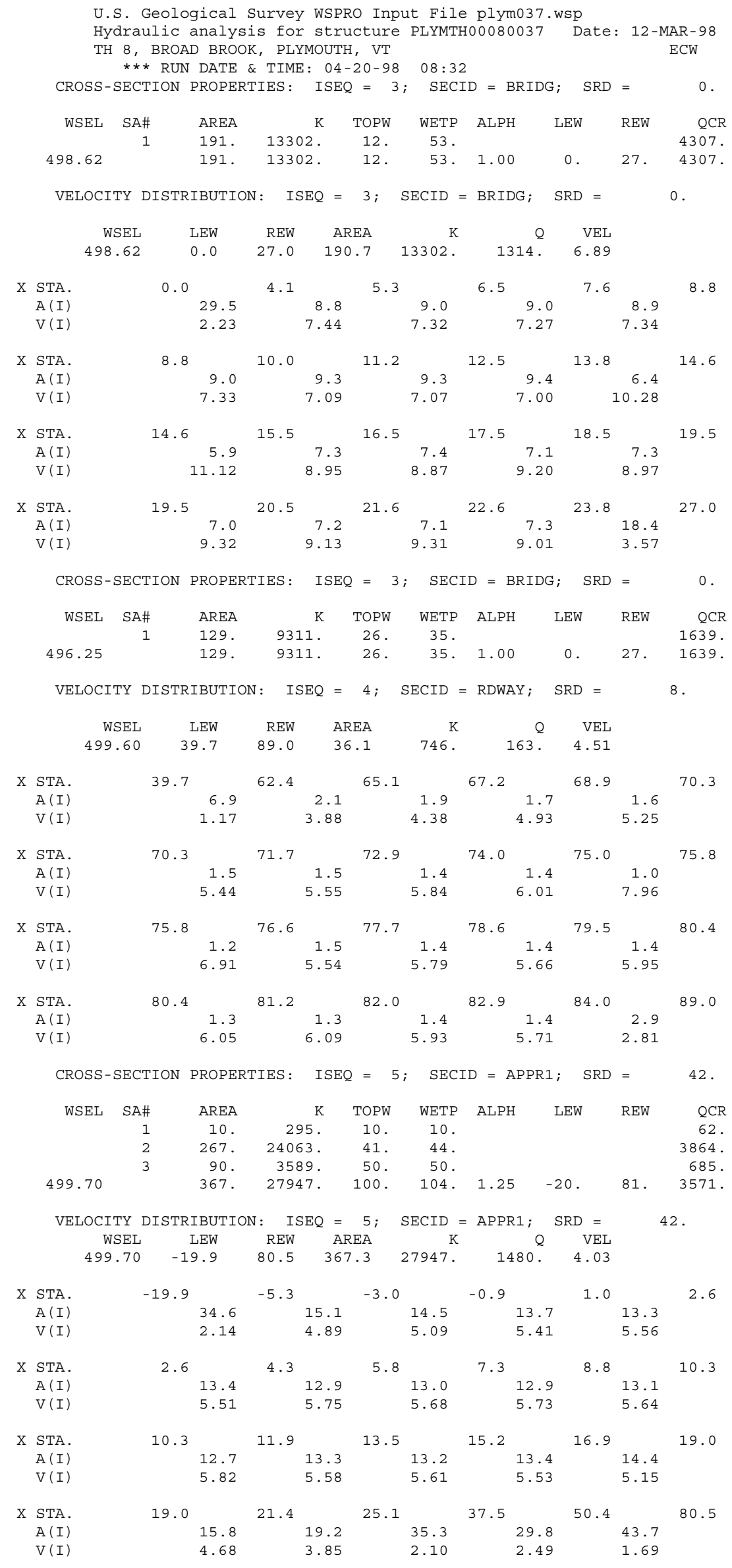




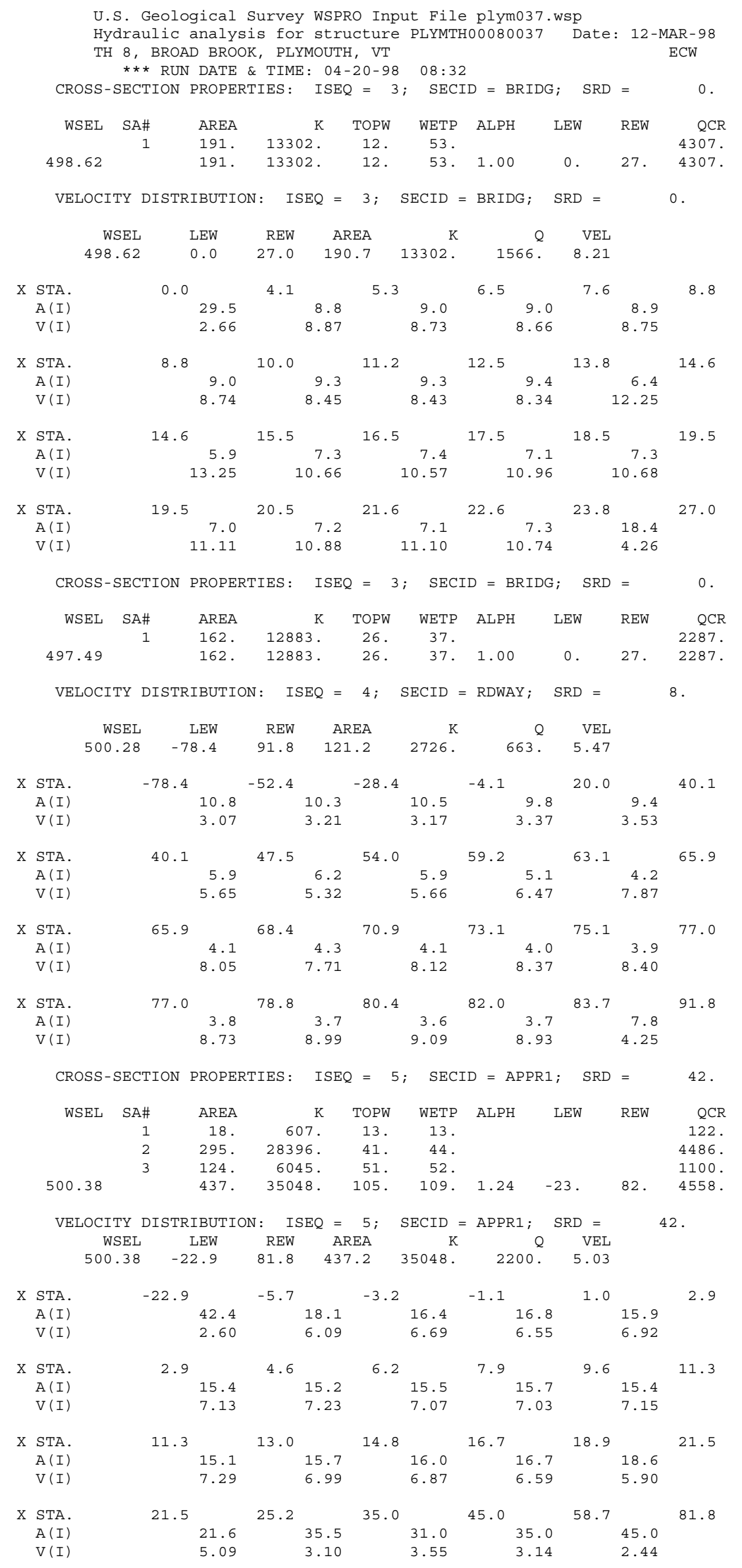


WSPRO OUTPUT FILE (continued)

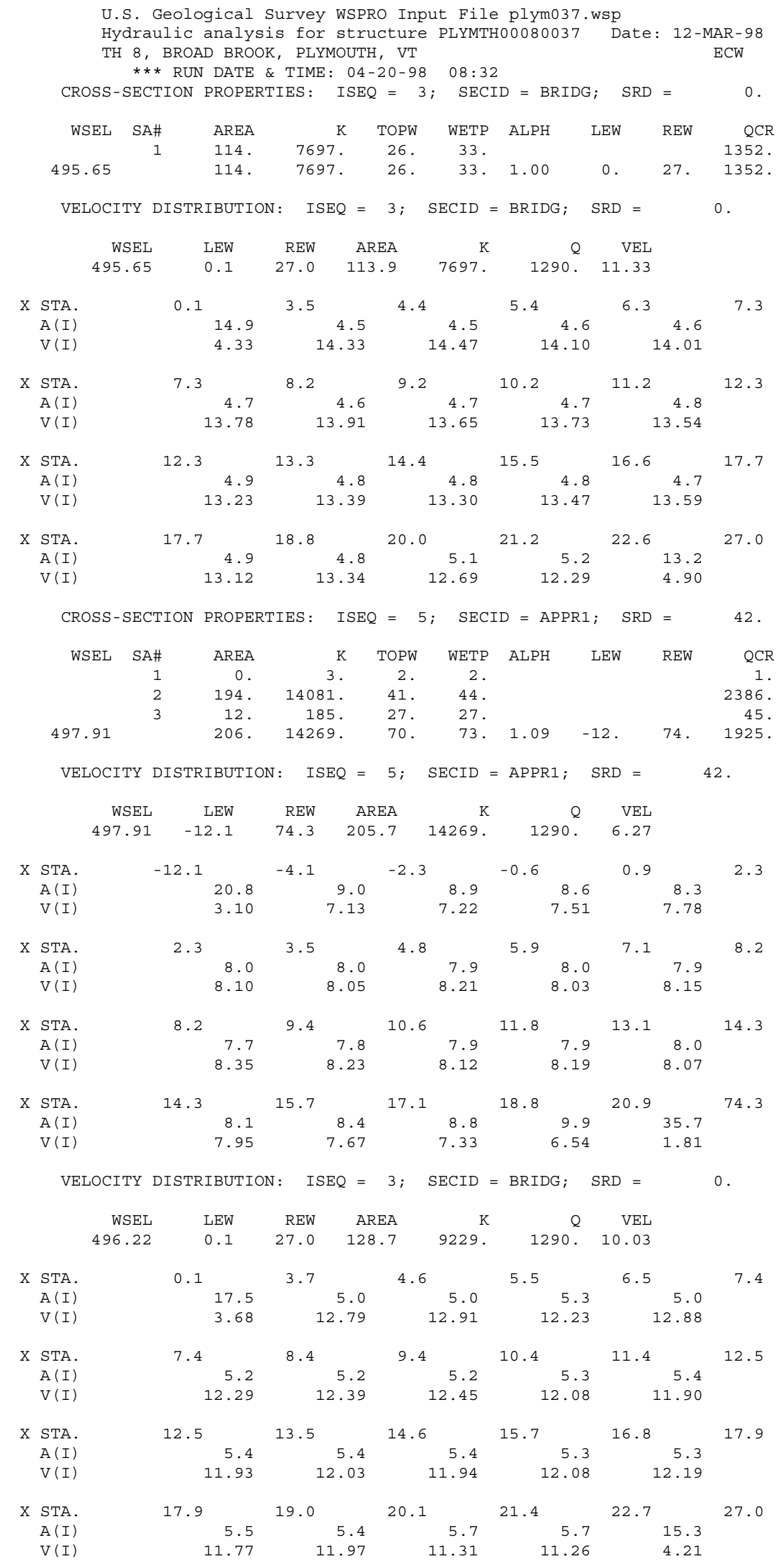


WSPRO OUTPUT FILE (continued)

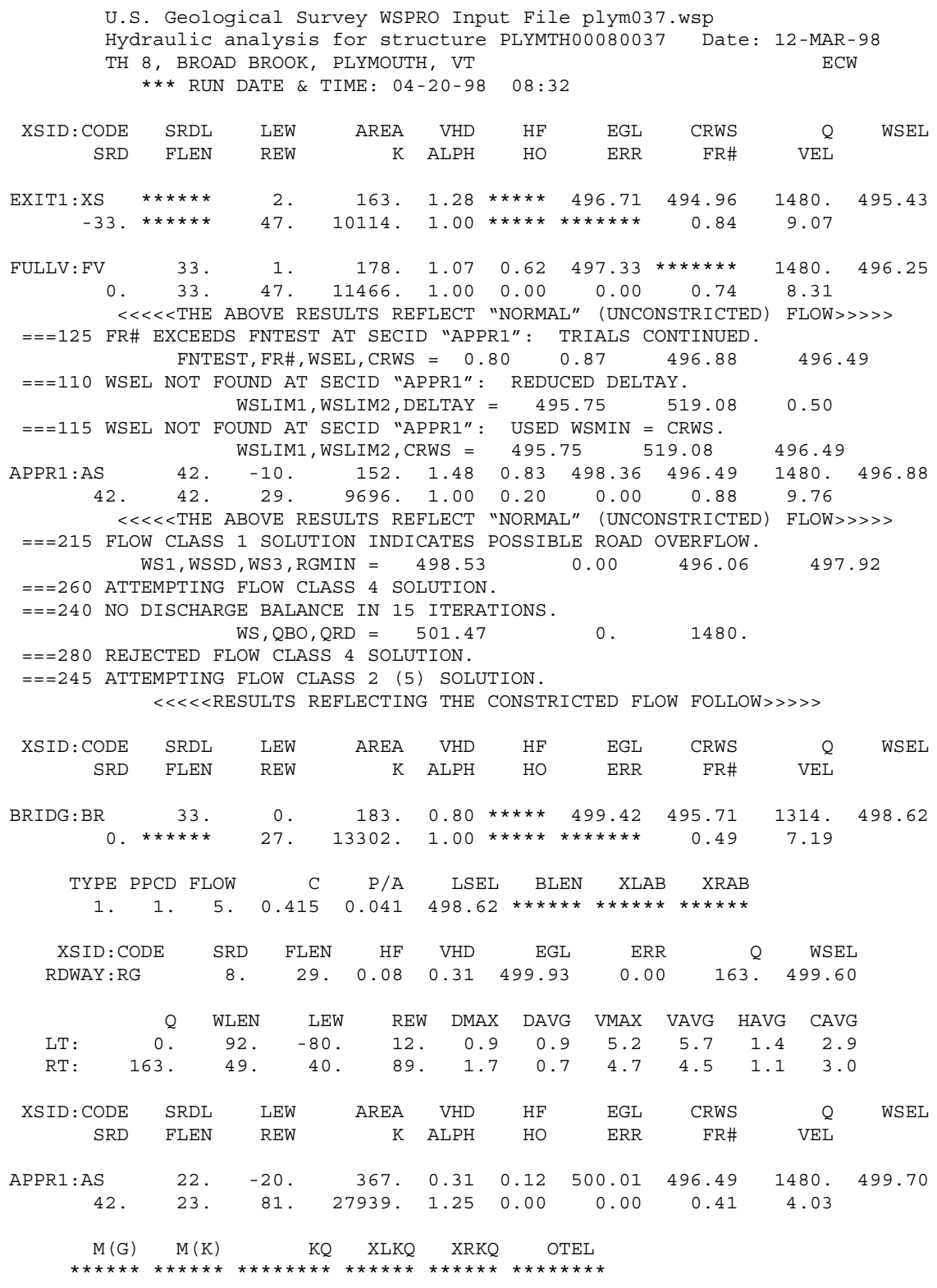

$<<<<<$ END OF BRIDGE COMPUTATIONS $>>>>>$

FIRST USER DEFINED TABLE.

\begin{tabular}{|c|c|c|c|c|c|c|c|c|}
\hline XSID : CODE & SRD & LEW & REW & $Q$ & $\mathrm{~K}$ & AREA & VEL & WSEL \\
\hline EXIT1:XS & -33 & 2 . & 47. & 1480. & 10114. & 163. & 9.07 & 495.43 \\
\hline FULLV : FV & 0 . & 1. & 47. & 1480. & 11466. & 178. & 8.31 & 496.25 \\
\hline BRIDG : BR & 0 . & 0 . & 27. & 1314. & 13302 . & 183. & 7.19 & 498.62 \\
\hline RDWAY : RG & 8 & $\star \star \star \star \star *$ & 0 . & 163 & 0 & $\star \star \star \star \star *$ & 2.00 & 499.60 \\
\hline APPR 1 : AS & 42 . & -20 & 81. & 1480 . & 27939 . & 367 . & 4.03 & 499.70 \\
\hline XSID : CODE & XLKQ & XRKQ & & & & & & \\
\hline
\end{tabular}

SECOND USER DEFINED TABLE.

$\begin{array}{lrrrrrrrrr}\text { XSID : CODE } & \text { CRWS } & \text { FR\# } & \text { YMIN } & \text { YMAX } & \text { HF } & \text { HO } & \text { VHD } & \text { EGL } & \text { WSEL } \\ \text { EXIT1:XS } & 494.96 & 0.84 & 490.14 & 515.20 * * * * * * * * * * * & 1.28 & 496.71 & 495.43 \\ \text { FULLV:FV } & * * * * * * * & 0.74 & 490.64 & 515.70 & 0.62 & 0.00 & 1.07 & 497.33 & 496.25 \\ \text { BRIDG:BR } & 495.71 & 0.49 & 490.55 & 498.68 * * * * * * * * * * * & 0.80 & 499.42 & 498.62 \\ \text { RDWAY:RG } & * * * * * * * * * * * * * * * & 497.92 & 512.74 & 0.08 * * * * * * & 0.31 & 499.93 & 499.60 \\ \text { APPR1:AS } & 496.49 & 0.41 & 490.94 & 519.08 & 0.12 & 0.00 & 0.31 & 500.01 & 499.70\end{array}$


WSPRO OUTPUT FILE (continued)

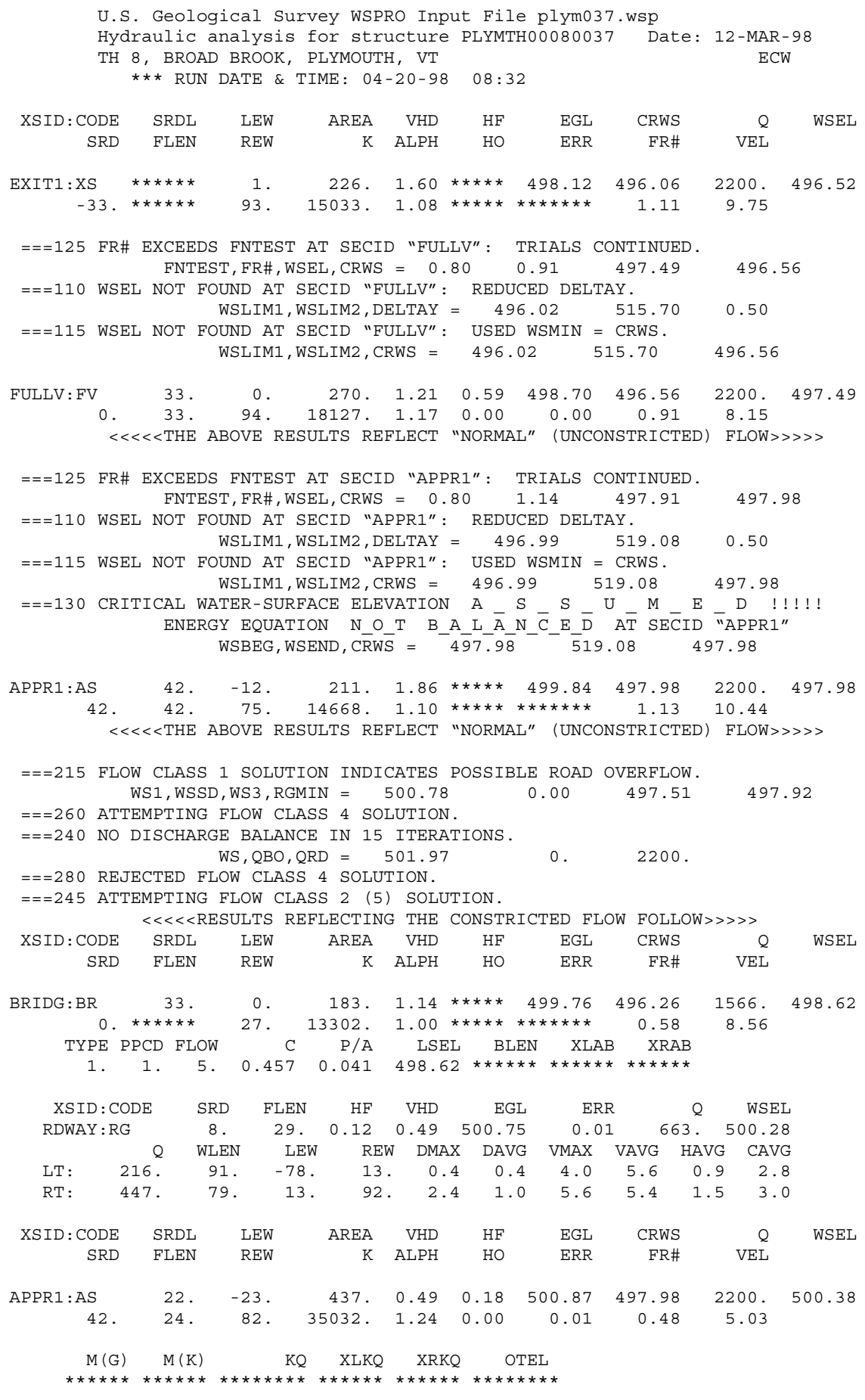

$<<<<$ END OF BRIDGE COMPUTATIONS $>>>>>$

FIRST USER DEFINED TABLE.

$\begin{array}{lrrrrrrrr}\text { XSID : CODE } & \text { SRD } & \text { LEW } & \text { REW } & Q & \text { K } & \text { AREA } & \text { VEL } & \text { WSEL } \\ \text { EXIT1 : XS } & -33 . & 1 . & 93 . & 2200 . & 15033 . & 226 . & 9.75 & 496.52 \\ \text { FULLV : FV } & 0 . & 0 . & 94 . & 2200 . & 18127 . & 270 . & 8.15 & 497.49 \\ \text { BRIDG : BR } & 0 . & 0 . & 27 . & 1566 . & 13302 . & 183 . & 8.56 & 498.62 \\ \text { RDWAY : RG } & 8 . * * * * * * * & 216 . & 663 . & 0 . * * * * * * * * & 2.00 & 500.28 \\ \text { APPR1 : AS } & 42 . & -23 . & 82 . & 2200 . & 35032 . & 437 . & 5.03 & 500.38\end{array}$

SECOND USER DEFINED TABLE.

\begin{tabular}{|c|c|c|c|c|c|c|c|c|c|}
\hline : CODE & CRWS & FR\# & YMIN & YMAX & $\mathrm{HF}$ & $\mathrm{HO}$ & VHD & EGL & \\
\hline EXIT & 496.06 & 1.11 & 490.14 & 515.20 * & 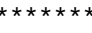 & 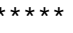 & 1.60 & 498.12 & \\
\hline UL & 6.56 & .91 & 90.64 & 515.70 & 0.59 & 0.00 & 1.21 & 8.70 & \\
\hline 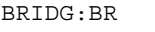 & 496.26 & 0.58 & 490.55 & $498.68 *$ & 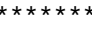 & 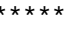 & 1.14 & 9.76 & 98 \\
\hline : RG & 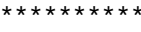 & $\star \star \star \star \star *$ & 497.92 & 512.74 & 0.12 ** & 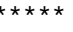 & 0.49 & 500.75 & 500 \\
\hline :AS & 497.98 & 0.48 & 490.94 & 519.08 & 0.18 & 0.00 & 0.49 & 500.87 & 500 \\
\hline
\end{tabular}


WSPRO OUTPUT FILE (continued)

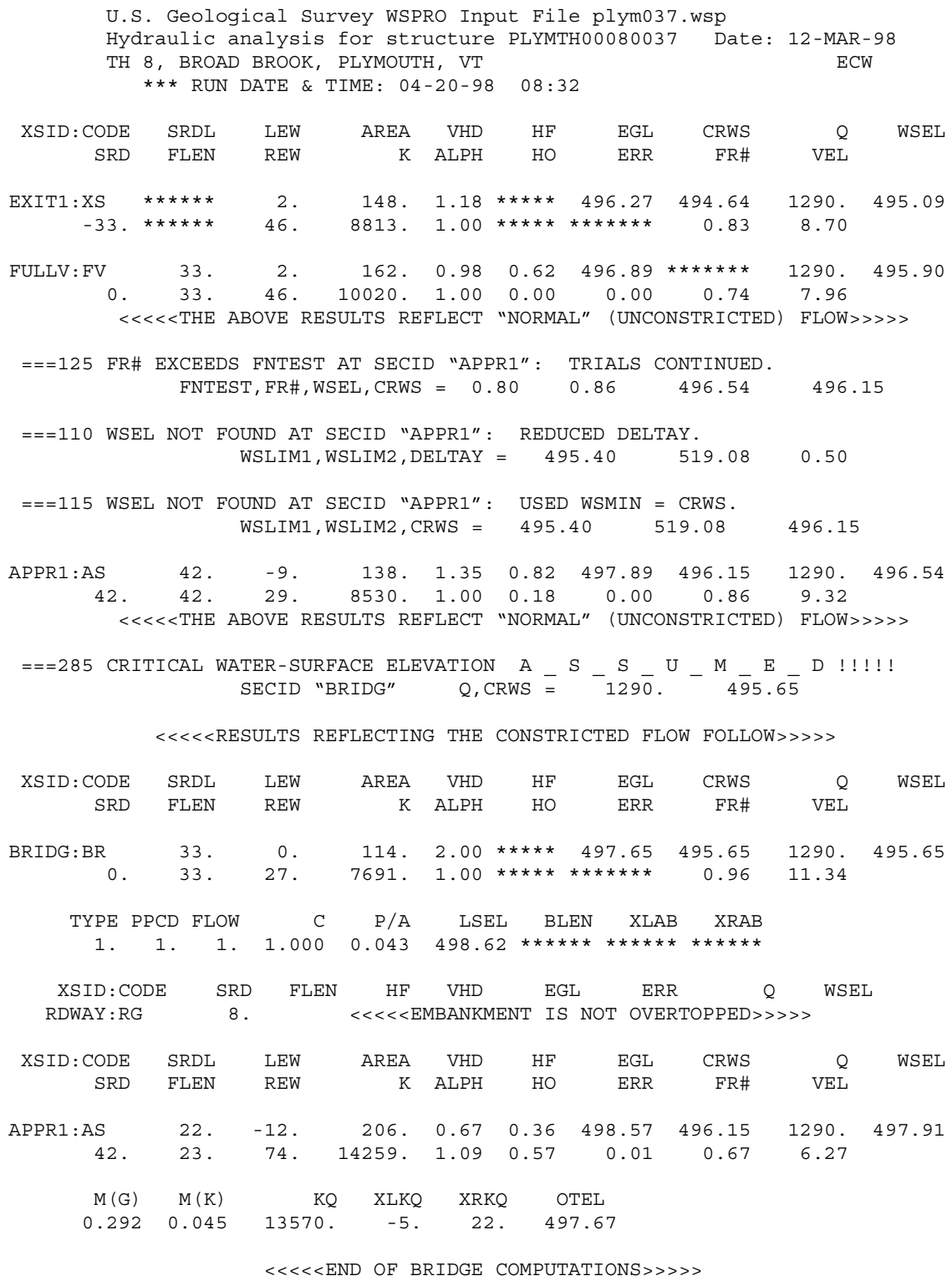

FIRST USER DEFINED TABLE.

\begin{tabular}{|c|c|c|c|c|c|c|c|c|}
\hline XSID : CODE & SRD & LEW & REW & $\mathrm{Q}$ & $\mathrm{K}$ & AREA & VEL & WSEL \\
\hline EXIT1:XS & -33 & 2 . & 46. & 1290. & 8813. & 148. & 8.70 & 495.09 \\
\hline FULLV : FV & 0 & 2 . & 46. & 1290. & 10020 . & 162. & 7.96 & 495.90 \\
\hline BRIDG : BR & 0 . & 0 & 27. & 1290. & 7691. & 114. & 11.34 & 495.65 \\
\hline RDWAY : RG & \multicolumn{3}{|c|}{$8 . * * \star * * * * * * * * * * *$} & \multicolumn{3}{|c|}{$0 . * * * * * * * * * * * * * * * * * *$} & \multicolumn{2}{|c|}{$2.00 * * * * * * * *$} \\
\hline APPR1 : AS & 42 . & -12 & 74. & 1290. & 14259 . & 206. & 6.27 & 497.91 \\
\hline XSID : CODE & XLKQ & XRKQ & & & & & & \\
\hline APPRI : AS & -5 & 22 . & 1357 & & & & & \\
\hline
\end{tabular}

SECOND USER DEFINED TABLE.

\begin{tabular}{|c|c|c|c|c|c|c|c|c|c|}
\hline XSID : CODE & CRWS & FR\# & YMIN & YMAX & $\mathrm{HF}$ & $\mathrm{HO}$ & VHD & EGL & WSEL \\
\hline EXIT1:XS & 494.64 & 0.83 & 490.14 & $515.20 * *$ & 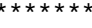 & $\star \star \star \star \star *$ & 1.18 & 496.27 & 495.09 \\
\hline FULLV : FV & 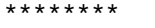 & 0.74 & 490.64 & 515.70 & 0.62 & 0.00 & 0.98 & 496.89 & 495.90 \\
\hline BRIDG : BR & 495.65 & 0.96 & 490.55 & $498.68 * *$ & $\star * \star * \star * \star *$ & $\star * \star * *$ & 2.00 & 497.65 & 495.65 \\
\hline RDWAY : RG & $\star \star \star \star \star * \star * \star * * \star * *$ & $\star * * * *$ & 497.92 & $512.74 * *$ & $\star \star \star \star \star * \star * *$ & $\star \star \star \star * * *$ & $\star \star \star \star * \star *$ & $\star \star \star \star \star \star * \star *$ & 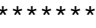 \\
\hline APPRI : AS & 496.15 & 0.67 & 490.94 & 519.08 & 0.36 & 0.57 & 0.67 & 498.57 & 497.91 \\
\hline
\end{tabular}

NORMAL END OF WSPRO EXECUTION. 


\section{APPENDIX C:}

\section{BED-MATERIAL PARTICLE-SIZE DISTRIBUTION}




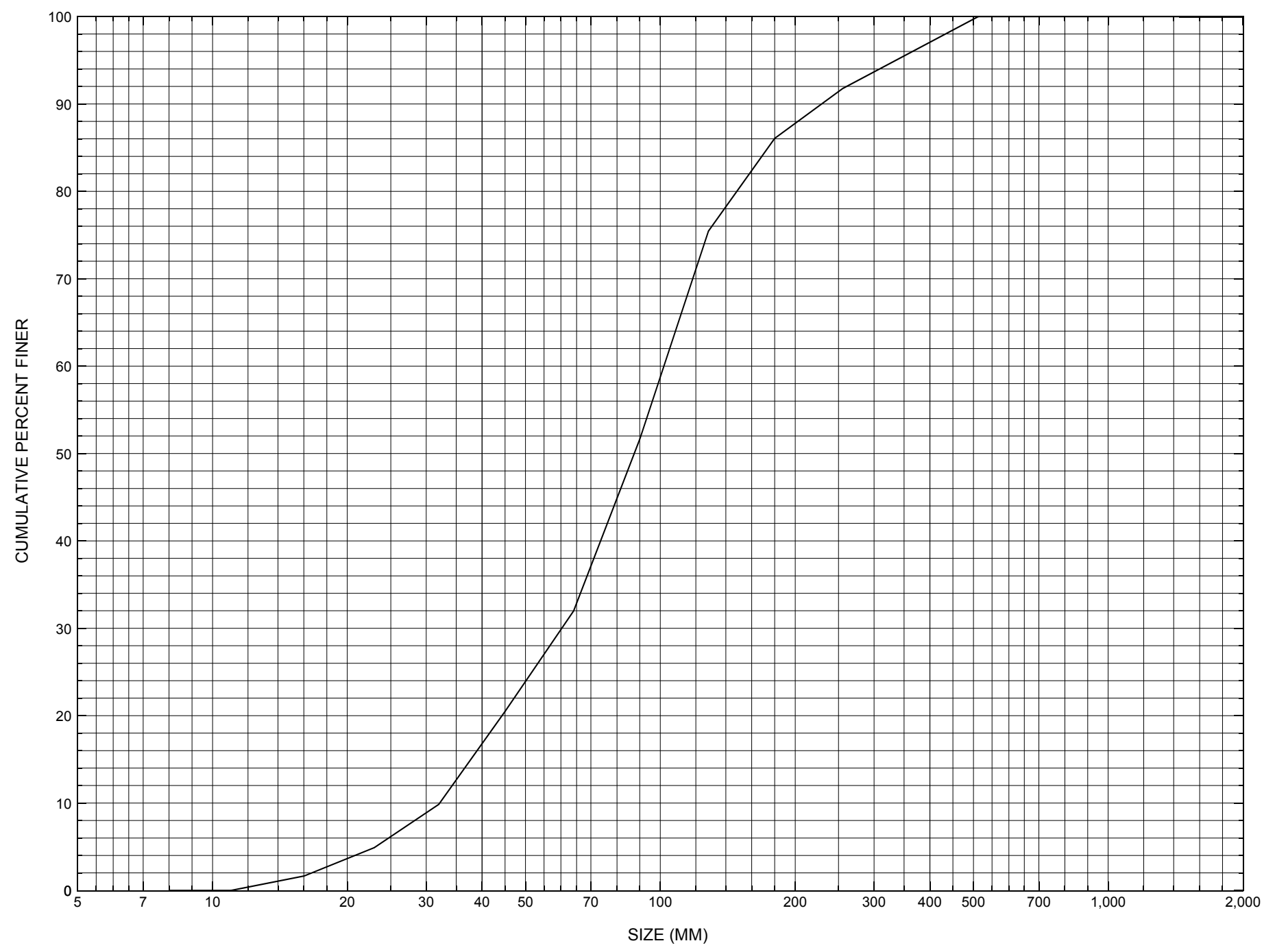

Appendix C. Bed material particle-size distribution for a pebble count in the channel approach of structure PLYMTH00080037, in Plymouth, Vermont. 


\section{APPENDIX D: \\ HISTORICAL DATA FORM}




\section{Structure Number PLYMTH00080037}

\section{General Location Descriptive}

Data collected by (First Initial, Full last name) $\mathbf{E}$. BOEHMLER

Date $(M M / D D / Y Y) \_\mathbf{0 3} / \underline{22} / \underline{95}$

Highway District Number (I - 2; nn) $\mathbf{0 3}$

Town (FIPS place code; I - 4; nnnnn) $\mathbf{5 6 0 5 0}$

Waterway (I - 6) BROAD BROOK

Route Number TH008

Topographic Map Plymouth

Latitude (I - 16; nnnn.n) $\mathbf{4 3 3 2 2}$
County (FIPS county code; I - 3; nnn)

Mile marker (I - 11; nnn.nnn) $\mathbf{0 0 0 0 0 0}$

Road Name (I - 7): -

Vicinity (I - 9) 0.5 MI TO JCT W CL3 TH5

Hydrologic Unit Code: $\mathbf{0 1 0 8 0 1 0 6}$

Longitude (i - 17; nnnnn.n) $\mathbf{7 2 4 0 4}$

\section{Select Federal Inventory Codes}

FHWA Structure Number (I - 8) $\mathbf{1 0 1 4 1 2 0 0 3 7 1 4 1 2}$

Maintenance responsibility $(I-21 ; n n) \quad \mathbf{0 3}$

Year built (I - 27; YYYY) 1974

Average daily traffic, ADT (I - 29; nnnnnn) 000040

Year of ADT (I - 30; YY) $\mathbf{9 1}$

Opening skew to Roadway $(I-34 ; n n) \quad 15$

Operational status $(I-41 ; X)$ D

Structure type (I- 43; nnn) $\mathbf{3 0 2}$

Approach span structure type $(I-44 ; n n n)$ 000

Number of spans (I - 45; nnn) $\mathbf{0 0 1}$

Number of approach spans (I - 46; nnnn) $\mathbf{0 0 0 0}$

Comments:

The structural inspection report of 6/14/93 indicates the structure is a steel stringer type bridge with a timber deck. The abutment walls and wingwalls are concrete. The left abutment and its wingwalls have a concrete footing and subfooting. The report notes some erosion present along the bottom of the footing of the left upstream wingwall. The footing concrete is noted as having minor surface spalling overall. A wooden beam bent is noted as having been added under the structure at midspan consisting of two vertical wood beams, two diagonal wood plank cross braces, and a $4 \times 4$ horizontal bearing beam at the top extending under all the steel stringers. Boulder stone fill protection is reported (Continued, page 33) 


\section{Bridge Hydrologic Data}

Is there hydrologic data available? $\underline{\mathbf{N}}$ if No, type ctrl-n $h \quad$ VTAOT Drainage area $\left(m i^{2}\right)$ : -

Terrain character:

Stream character \& type: -

Streambed material:

Discharge Data (cfs):

$$
\begin{aligned}
& Q_{2.33}- \\
& Q_{50}-
\end{aligned}
$$

Record flood date $(M M / D D / Y Y)$ :

Estimated Discharge (cfs): Ice conditions (Heavy, Moderate, Light) : -

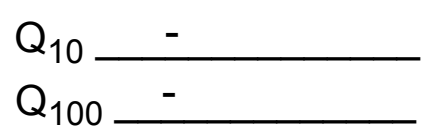

$$
\begin{aligned}
& Q_{25}- \\
& Q_{500}-
\end{aligned}
$$

Water surface elevation $(f t):-$

The stage increases to maximum highwater elevation (Rapidly, Not rapidly):

The stream response is (Flashy, Not flashy):

Describe any significant site conditions upstream or downstream that may influence the stream's stage: -

Watershed storage area (in percent): _ _ \%

The watershed storage area is: - (1-mainly at the headwaters; 2- uniformly distributed; 3-immediatly upstream oi the site)

Water Surface Elevation Estimates for Existing Structure:

\begin{tabular}{|l|l|l|l|l|l|}
\hline Peak discharge frequency & $Q_{2.33}$ & $Q_{10}$ & $Q_{25}$ & $Q_{50}$ & $Q_{100}$ \\
Water surface elevation (ft)) & - & - & - & - & - \\
Velocity (ft/sec) & - & - & - & - & - \\
\hline
\end{tabular}

Long term stream bed changes: -

Is the roadway overtopped below the $\mathrm{Q}_{100}$ ? (Yes, No, Unknown): $\mathbf{U}$ Frequency: Relief Elevation (ft): Discharge over roadway at $Q_{100}\left(f^{3} / \mathrm{sec}\right)$ :

Are there other structures nearby? (Yes, No, Unknown): $\underline{\mathbf{U}}$ Upstream distance (miles): Town: If No or Unknown, type ctrl-n os Highway No. : Structure No. : Year Built:

Clear span (ft): Clear Height $(f t)$ : Full Waterway $\left(f^{2}\right)$ : 
Downstream distance (miles): Town: Year Built:

Highway No. : Structure No. : Structure Type:

Clear span (ft): Clear Height (ft): Full Waterway $\left(f^{2}\right)$ :

Comments:

around the vertical beams of the bent. The wooden bent here is considered a temporary repair. Some stone fill is reported in front of the right abutment and its wingwalls. In front of the downstream end of the downstream left wingwall and of the left abutment, stone fill was also noted as present. In addition, stone fill was reported as visible along the banks upstream and downstream.

\section{USGS Watershed Data}

Watershed Hydrographic Data

Drainage area (DA)

Watershed storage (ST)

5.55 $\mathrm{mi}^{2}$ Lake/pond/swamp area $\mathbf{0}$ $\mathrm{mi}^{2}$

Bridge site elevation 1230

Main channel length 3.51 $\mathrm{ft}$ $\%$

$10 \%$ channel length elevation $\mathbf{1 2 8 0}$ $\mathrm{mi}$

Headwater elevation 2360 $\mathrm{ft}$

Main channel slope $(S)$

(S) 220.32 $\mathrm{ft} / \mathrm{mi}$

Watershed Precipitation Data

Average site precipitation in Average headwater precipitation in

Maximum 2yr-24hr precipitation event $(124,2)$ in

Average seasonal snowfall (Sn) $\mathrm{ft}$ 


\section{Bridge Plan Data}

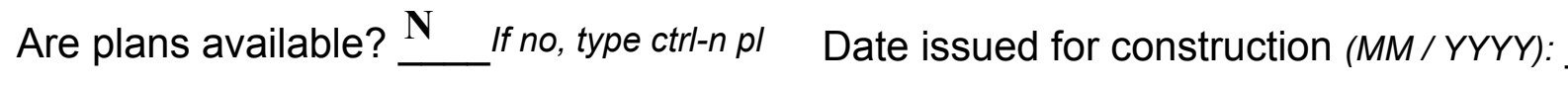

Project Number

Minimum channel bed elevation:

Low superstructure elevation: USLAB DSLAB USRAB DSRAB Benchmark location description:

NO BENCHMARK INFORMATION

Reference Point (MSL, Arbitrary, Other): Datum (NAD27, NAD83, Other):

Foundation Type: 4

If 1 : Footing Thickness

If 2: Pile Type:

If 3: Footing bottom elevation:

Is boring information available? $\mathbf{N}$

Foundation Material Type: $\mathbf{3}$

(1-Spreadfooting; 2-Pile; 3- Gravity; 4-Unknown)

Footing bottom elevation: -

Briefly describe material at foundation bottom elevation or around piles:

NO FOUNDATION MATERIAL INFORMATION 


\section{Cross-sectional Data}

Is cross-sectional data available? Yes If no, type ctrl-n xs

Source (FEMA, VTAOT, Other)? VTAOT

This section was created from a sketch dated $6 / 15 / 93$ that was attached to a bridge inspection Comments: report. This section was taken at the US bridge face. The low chord elevations are the same as the DS face used in this report that was surveyed 10/3/95.

\begin{tabular}{|l|l|l|l|l|l|l|l|l|l|l|l|}
\hline Station & $\mathbf{0}$ & $\mathbf{1}$ & $\mathbf{8}$ & $\mathbf{1 2}$ & $\mathbf{1 7}$ & $\mathbf{2 1}$ & $\mathbf{2 7}$ & $\mathbf{2 8}$ & - & - & - \\
\hline Feature & LAB & - & - & - & - & - & - & $\mathrm{RAB}$ & - & - & - \\
\hline $\begin{array}{l}\text { Low chord } \\
\text { elevation }\end{array}$ & $\mathbf{4 9 8 . 6 0}$ & $\mathbf{4 9 8 . 6 0}$ & $\mathbf{4 9 8 . 6 0}$ & $\mathbf{4 9 8 . 6 0}$ & $\mathbf{4 9 8 . 6 0}$ & $\mathbf{4 9 8 . 6 0}$ & $\mathbf{4 9 8 . 6 0}$ & $\mathbf{4 9 8 . 6 0}$ & - & - & - \\
\hline $\begin{array}{l}\text { Bed } \\
\text { elevation }\end{array}$ & $\mathbf{4 9 2 . 7 5}$ & $\mathbf{4 9 2 . 7 5}$ & $\mathbf{4 9 0 . 6 0}$ & $\mathbf{4 9 0 . 6 0}$ & $\mathbf{4 9 0 . 8 0}$ & $\mathbf{4 9 0 . 8 0}$ & $\mathbf{4 9 2 . 6 0}$ & $\mathbf{4 9 2 . 6 0}$ & - & - & - \\
\hline $\begin{array}{l}\text { Low chord } \\
\text { to bed }\end{array}$ & $\mathbf{5 . 8 5}$ & $\mathbf{5 . 8 5}$ & $\mathbf{8 . 0 0}$ & $\mathbf{8 . 0 0}$ & $\mathbf{7 . 8 0}$ & $\mathbf{7 . 8 0}$ & $\mathbf{6 . 0 0}$ & $\mathbf{6 . 0 0}$ & - & - & - \\
\hline Station & - & - & - & - & - & - & - & - & - & - & - \\
\hline Feature & - & - & - & - & - & - & - & - & - & - & - \\
\hline $\begin{array}{l}\text { Low chord } \\
\text { elevation }\end{array}$ & - & - & - & - & - & - & - & - & - & - & - \\
\hline $\begin{array}{l}\text { Bed } \\
\text { elevation }\end{array}$ & - & - & - & - & - & - & - & - & - & - & - \\
\hline $\begin{array}{l}\text { Low chord } \\
\text { to bed }\end{array}$ & - & - & - & - & - & - & - & - & - & - & - \\
\hline
\end{tabular}

Source (FEMA, VTAOT, Other)?

Comments: -

\begin{tabular}{|l|l|l|l|l|l|l|l|l|l|l|l|}
\hline Station & - & - & - & - & - & - & - & - & - & - & - \\
\hline Feature & - & - & - & - & - & - & - & - & - & - & - \\
\hline $\begin{array}{l}\text { Low chord } \\
\text { elevation }\end{array}$ & - & - & - & - & - & - & - & - & - & - & - \\
\hline $\begin{array}{l}\text { Bed } \\
\text { elevation }\end{array}$ & - & - & - & - & - & - & - & - & - & - & - \\
\hline $\begin{array}{l}\text { Low chord } \\
\text { to bed }\end{array}$ & - & - & - & - & - & - & - & - & - & - & - \\
\hline Station & - & - & - & - & - & - & - & - & - & - & - \\
\hline Feature & - & - & - & - & - & - & - & - & - & - & - \\
\hline $\begin{array}{l}\text { Low chord } \\
\text { elevation }\end{array}$ & - & - & - & - & - & - & - & - & - & - & - \\
\hline $\begin{array}{l}\text { Bed } \\
\text { levation }\end{array}$ & - & - & - & - & - & - & - & - & - & - & - \\
\hline $\begin{array}{l}\text { Low chord } \\
\text { to bed }\end{array}$ & - & - & - & - & - & - & - & - & - & - & - \\
\hline
\end{tabular}




\section{APPENDIX E: \\ LEVEL I DATA FORM}


U. S. Geological Survey

Bridge Field Data Collection and Processing Form

Qa/Qc Check by: $\mathbf{C G}$ Date: $\mathbf{0 2 / 1 4 / 9 6}$

\section{Structure Number}

PLYMTH00080037 Date: $\mathbf{0 2 / 1 5 / 9 6}$

\section{A. General Location Descriptive}

1. Data collected by (First Initial, Full last name) $\underline{\mathbf{L}}$. Medalie

Date $(M M / D D / Y Y)$

$10 / 03$

/ 1995

2. Highway District Number $\mathbf{0 3}$

County Windsor (027)

Mile marker -

Waterway (I - 6) Broad Brook

Route Number TH 08

Town Plymouth (56050)

Road Name -

Hydrologic Unit Code: 01080106

3. Descriptive comments:

The bridge is located 0.5 miles to the junction with CL3 TH5.

\section{B. Bridge Deck Observations}
4. Surface cover... LBUS 6
RBUS 6
LBDS 6
RBDS 6
Overall 6

(2b us,ds,lb,rb: 1- Urban; 2- Suburban; 3- Row crops; 4- Pasture; 5- Shrub- and brushland; 6- Forest; 7- Wetland)
5. Ambient water surface... US 2
UB 1
DS 2
(1- pool; 2- riffle)

6. Bridge structure type 1 (1- single span; 2- multiple span; 3- single arch; 4- multiple arch; 5-cylindrical culvert; 6- box culvert; or 7- other)
7. Bridge length $\mathbf{3 1}$
(feet)
Span length $\underline{\mathbf{2 8}}$
(feet)
Bridge width 12.8 (feet)

\section{Road approach to bridge:}
8. LB 1 RB 1
( 0 even, 1- lower, 2- higher)
9. LB_2
RB $\underline{2}$
(1-Paved, 2- Not paved)

10. Embankment slope (run / rise in feet / foot)

US left

US right

\begin{tabular}{|c|c|c|c|}
\hline \multicolumn{2}{|c|}{ Protection } & \multirow{2}{*}{ 13.Erosion } & 14.Severity \\
\hline 11.Type & 12.Cond. & $\underline{\mathbf{2}}$ & $\mathbf{1}$ \\
\hline $\mathbf{0}$ & - & $\mathbf{2}$ & $\mathbf{1}$ \\
\hline $\mathbf{1}$ & $\mathbf{2}$ & $\underline{\mathbf{2}}$ & $\underline{\mathbf{1}}$ \\
\hline $\mathbf{0}$ & - & $\underline{\mathbf{2}}$ & $\mathbf{1}$ \\
\hline $\mathbf{2}$ & $\mathbf{1}$ & $\underline{\mathbf{2}}$ \\
\hline
\end{tabular}

Bank protection types: 0- none; 1- < 12 inches,

2- $<36$ inches; $3-<48$ inches;

4- < 60 inches; 5- wall / artificial levee

Bank protection conditions: 1- good; 2- slumped;

3- eroded; 4- failed

Erosion: 0 - none; 1- channel erosion; 2 -

road wash; 3- both; 4- other

Erosion Severity: 0 - none; 1- slight; 2- moderate; 3- severe

Channel approach to bridge (BF):

15. Angle of approach: $\mathbf{0}$

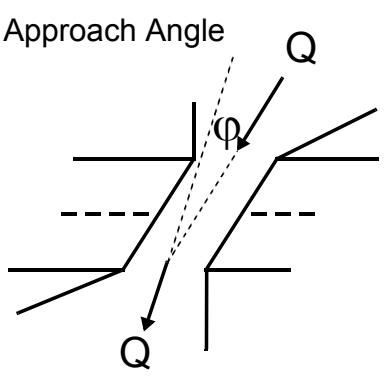

17. Channel impact zone 1 :

Where? LB $(L B, R B)$

Range? 35 feet US

Channel impact zone 2:

Where? _ _ $(L B, R B)$

Range? - $\quad$ feet -

(US, UB, DS) to Impact Severity: 0- none to very slight; 1- Slight; 2- Moderate; 3- Severe feet -

16. Bridge skew: 15 Bridge Skew Angle

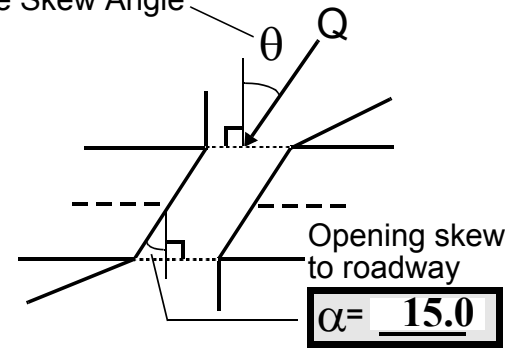

\section{Exist? $\mathbf{Y}(Y$ or $N)$}

Severity 1

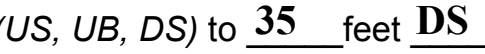

Exist? $\mathbf{N} \quad($ Yor $N)$

Severity - 
18. Bridge Type: 1a

1a- Vertical abutments with wingwalls

1 b- Vertical abutments without wingwalls

2- Vertical abutments and wingwalls, sloping embankment Wingwalls parallel to abut. face

3- Spill through abutments

4- Sloping embankment, vertical wingwalls and abutments

Wingwall angle less than $90^{\circ}$.

19. Bridge Deck Comments (surface cover variations, measured bridge and span lengths, bridge type variations, approach overflow width, etc.)

7. The values are from the VTAOT. During the site visit, the measured bridge length was 30.2 feet, the span length was 27.5 feet and the deck width was 16 feet.

11. The right bank upstream protection stone fill material is very loose and slumped.

13. The left bank downstream has a moderately sized road wash channel between the end of the wingwall and the stone protection.

\section{Upstream Channel Assessment}

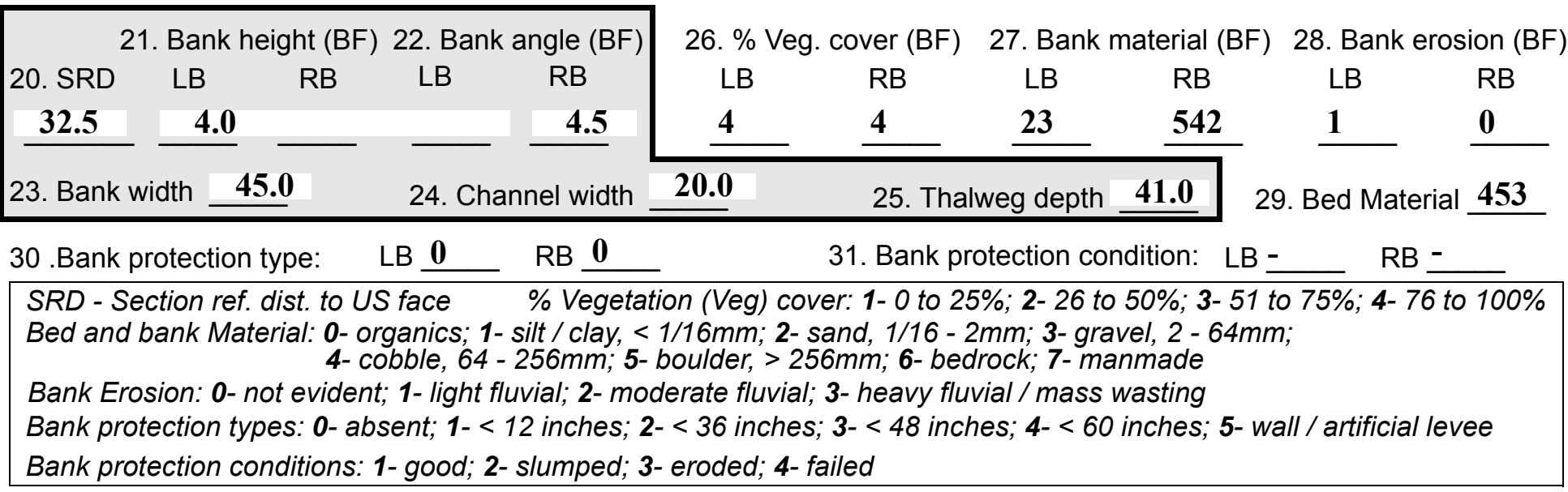

32. Comments (bank material variation, minor inflows, protection extent, etc.):

The channel is all riffle to $\mathbf{1 0}$ feet upstream where it flattens to a pool under the bridge. 
33.Point/Side bar present? $\mathbf{N}(Y$ or $N$. if $N$ type ctrl-n pb)34. Mid-bar distance: -

35. Mid-bar width: -

36. Point bar extent: feet (US, UB) to feet -

(US, UB, DS) positioned $\%$ LB to $\%$ RB

37. Material: -

38. Point or side bar comments (Circle Point or Side; Note additional bars, material variation, status, etc.):

NO POINT BARS

39. Is a cut-bank present? $\underline{\mathbf{Y}}$ ( $Y$ or if $N$ type $c t r-n c b)$ 40. Where? $\underline{\mathbf{L B}}(\mathrm{LB}$ or $R B)$

41. Mid-bank distance: 33

42. Cut bank extent: 55 feet $\underline{\mathbf{U S}}$ (US, UB) to $\underline{4}$ feet $\underline{\mathbf{U S}}$ (US, UB, DS)

43. Bank damage: 1 (1- eroded and/or creep; 2- slip failure; 3- block failure)

44. Cut bank comments (eg. additional cut banks, protection condition, etc.):

The cut-bank extends to the upstream end of the left wingwall.

On the right bank starting from the culvert (refer to no. 54) to approximately $100 \mathrm{ft}$ upstream, there is severe bank erosion which undercuts the road in spots. There are large (12 inch diameter) trees across the stream from both sides of the stream.

45. Is channel scour present? $\mathbf{N}$ (Yor if $N$ type ctrl-n cs) 46. Mid-scour distance: -

47. Scour dimensions: Length Width Depth : Position \%LB to $\% \mathrm{RB}$

48. Scour comments (eg. additional scour areas, local scouring process, etc.):

NO CHANNEL SCOUR

There are a few small 1-2 feet square holes near boulders 5 and 9 feet upstream of the bridge deck in the center of the channel.

49. Are there major confluences? $\mathbf{N}$ (Y or if $N$ type ctrl-n $m c)$

51. Confluence 1: Distance 52. Enters on (LB or $R B)$ Confluence 2: Distance Enters on (LB or $R B)$

54. Confluence comments (eg. confluence name):

\section{NO MAJOR CONFLUENCES}

There is a culvert pipe under TH 8 at 135 feet upstream; it enters on the right.
50. How many? -

53. Type(1- perennial; 2- ephemeral)

Type (1-perennial; 2-ephemeral)

\section{Under Bridge Channel Assessment}

55. Channel restraint (BF)? LB 2

\begin{tabular}{|ccccc|}
\hline \multicolumn{2}{|c|}{56. Height (BF) } & \multicolumn{3}{c}{57 Angle (BF) } \\
LB & RB & LB & RB \\
$\mathbf{2 6 . 0}$ & & & $\mathbf{1 . 0}$ & \\
\hline
\end{tabular}
(1- natural bank; 2- abutment; 3- artificial levee)

58. Bank width (BF) -

59. Channel width -

61. Material (BF)

LB RB

$2 \quad 7$
62. Erosion (BF)

LB RB

7

Bed and bank Material: 0- organics; 1- silt / clay, < 1/16mm; 2- sand, 1/16 - 2mm; 3- gravel, 2 - 64mm; 4- cobble, 64 - 256mm; 5- boulder, > 256mm; 6- bedrock; 7- manmade

Bank Erosion: 0- not evident; 1- light fluvial; 2- moderate fluvial; 3- heavy fluvial / mass wasting

64. Comments (bank material variation, minor inflows, protection extent, etc.):

435

There are two very unnatural holes (about 1 foot square) in the bank and protection material along the right abutment. The bed under the bridge consists of cobbles, gravel, boulders and timber shavings. 
65. Debris and Ice Is there debris accumulation?

$(Y$ or $N)$ 66. Where? $\underline{Y}$

(1- Upstream; 2- At bridge; 3- Both)

67. Debris Potential $\underline{2}$

( 1- Low; 2- Moderate; 3- High)

68. Capture Efficiency 3

(1- Low; 2- Moderate; 3- High)

69. Is there evidence of ice build-up? $\underline{\mathbf{3}}$ (Y or $N)$

Ice Blockage Potential $\mathbf{N}$

(1-Low; 2- Moderate; 3- High)

70. Debris and Ice Comments:

3

The debris at bridge may be mostly scraps from new timber deck. The center pier may act as a capture zone.

\begin{tabular}{|l|c|c|c|c|c|c|c|c|}
\hline Abutments & $\begin{array}{c}\text { 71. Attack } \\
\angle \mathrm{BF})\end{array}$ & $\begin{array}{c}\text { 72. Slope } \\
(\mathrm{Qmax})\end{array}$ & $\begin{array}{c}\text { 73. Toe } \\
\text { loc. (BF) }\end{array}$ & $\begin{array}{c}\text { 74. Scour } \\
\text { Condition }\end{array}$ & $\begin{array}{c}\text { 75. Scour } \\
\text { depth }\end{array}$ & $\begin{array}{c}\text { 76. Exposure } \\
\text { depth }\end{array}$ & 77. Material & 78. Length \\
\hline LABUT & & $\mathbf{1 5}$ & $\mathbf{9 0}$ & $\mathbf{2}$ & $\mathbf{2}$ & - & $\mathbf{1}$ & $\mathbf{9 0 . 0}$ \\
\hline RABUT & $\mathbf{1}$ & $\mathbf{0}$ & $\mathbf{9 0}$ & & & $\mathbf{0}$ & $\mathbf{2}$ & $\mathbf{2 6 . 0}$ \\
\hline
\end{tabular}

Pushed: $L B$ or RB

Toe Location (Loc.): 0- even, 1- set back, 2- protrudes

Scour cond.: 0- not evident; 1- evident (comment); 2- footing exposed; 3-undermined footing; 4- piling exposed; 5- settled; 6- failed

Materials: 1- Concrete; 2- Stone masonry or drywall; 3- steel or metal; 4- wood

79. Abutment comments (eg. undermined penetration, unusual scour processes, debris, etc.):

0.5

1

76. The left abutment subfooting is exposed a maximum of 1 foot at the downstream end. The subfooting is exposed from the downstream end of the abutment to 4.5 feet under the bridge (measured horizontally). The footing is exposed 0.75 feet at the upstream end to its complete height of 1.25 feet at the downstream end.

The right abutment footing is only exposed for 2 feet toward the downstream end.

80. Wingwalls: $\begin{array}{lllll} & & & & \\ \text { Exist? } & \text { Material? } & \text { Scour } & \text { Scour } & \text { Exposure } \\ \text { Condition? } & \text { depth? } & \text { depth? }\end{array}$

USLWW:

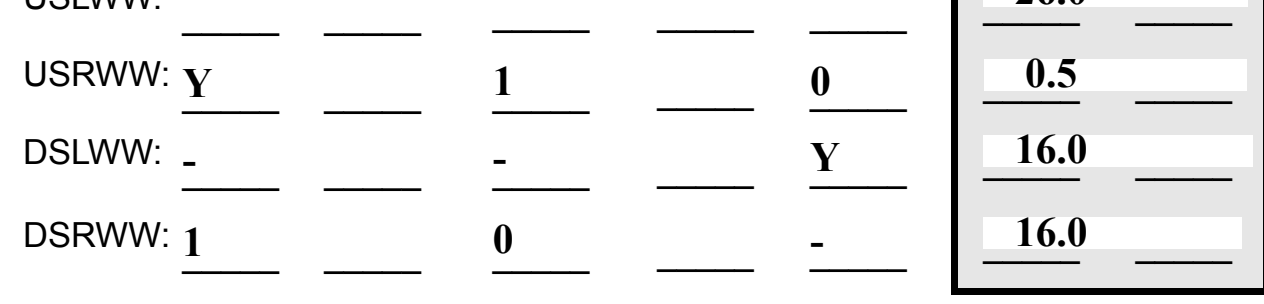

Wingwall materials: 1- Concrete; 2- Stone masonry or drywall; 3- steel or metal; 4- wood

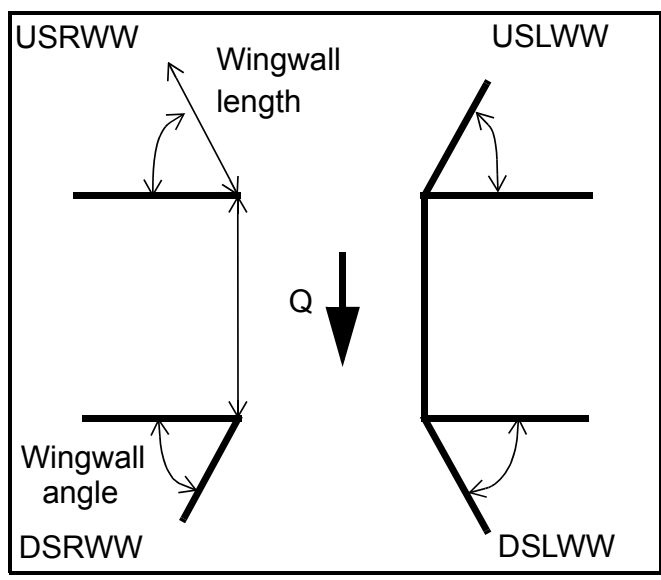

82. Bank / Bridge Protection:

\begin{tabular}{|l|l|l|l|l|l|l|c|c|}
\hline Location & USLWW & USRWW & LABUT & RABUT & LB & RB & DSLWW & DSRWW \\
\hline Type & - & $\mathbf{3}$ & $\mathbf{Y}$ & - & $\mathbf{1}$ & $\mathbf{1}$ & $\mathbf{1}$ & $\mathbf{1}$ \\
\hline Condition & $\mathbf{Y}$ & - & $\mathbf{1}$ & - & $\mathbf{1}$ & $\mathbf{1}$ & $\mathbf{2}$ & $\mathbf{1}$ \\
\hline Extent & $\mathbf{1}$ & $\mathbf{2}$ & $\mathbf{0}$ & $\mathbf{2}$ & $\mathbf{1}$ & $\mathbf{2}$ & $\mathbf{1}$ & - \\
\hline
\end{tabular}

Bank / Bridge protection types: 0- absent; 1- < 12 inches; 2- < 36 inches; 3- < 48 inches; 4- < 60 inches; 
83. Wingwall and protection comments (eg. undermined penetration, unusual scour processes, etc.):

-
-
-
-
-
2
1
3
1
1
1

Piers:

84. Are there piers? Th (Y or if N type ctrl-n pr)

\begin{tabular}{|l|r|r|r|r|l|l|l|}
\hline \multirow{2}{*}{$\begin{array}{l}85 . \\
\text { Pier no. }\end{array}$} & \multicolumn{3}{|c|}{ width (w) feet } & \multicolumn{3}{c|}{ elevation (e) feet } \\
\cline { 2 - 8 } & w1 & w2 & w3 & e@w1 & e@w2 & e@w3 \\
\hline Pier 1 & & $\mathbf{7 . 5}$ & $\mathbf{5 . 5}$ & $\mathbf{6 0 . 0}$ & $\mathbf{2 5 . 0}$ & $\mathbf{3 0 . 0}$ \\
\hline Pier 2 & $\mathbf{7 . 5}$ & $\mathbf{5 . 5}$ & & $\mathbf{6 0 . 0}$ & $\mathbf{1 . 0}$ & $\mathbf{4 9 0 . 7 8}$ \\
\hline Pier 3 & - & - & - & - & - & - \\
\hline Pier 4 & - & - & - & - & - & - \\
-
\end{tabular}

\begin{tabular}{|l|l|l|l|l|}
\hline Level 1 Pier Descr. & \multicolumn{1}{|c|}{1} & \multicolumn{1}{|c|}{2} & 3 & \multicolumn{1}{|c|}{4} \\
\hline 86. Location (BF) & e & foot- & & 2 \\
\hline 87. Type & upst & ing is & & 2 \\
\hline 88. Material & ream & expo & & $\mathbf{0}$ \\
\hline 89. Shape & end & sed 2 & Y & - \\
\hline 90. Inclined? & of & feet. & MC & - \\
\hline 91. Attack $\angle$ (BF) & the & & M & - \\
\hline 92. Pushed & dow & & $\mathbf{3}$ & - \\
\hline 93. Length (feet) & - & - & - & - \\
\hline 94. \# of piles & nstre & & $\mathbf{1}$ & - \\
\hline 95. Cross-members & am & & $\mathbf{2}$ & - \\
\hline 96. Scour Condition & left & & N & - \\
\hline 97. Scour depth & wing & & $\mathbf{1 0}$ & - \\
\hline 98. Exposure depth & wall & & LB & - \\
\hline
\end{tabular}

LFP, LTB, LB, MCL, MCM, MCR, RB, RTB, RFP

1- Solid pier, 2- column, 3- bent

1-Wood; 2- concrete; 3- metal; 4- stone

1- Round; 2- Square; 3- Pointed

Y-yes; $N-$ no

$L B$ or $R B$

0- none; 1- laterals; 2- diagonals; 3- both

0- not evident; 1- evident (comment);

2- footing exposed; 3- piling exposed;

4- undermined footing; 5- settled; 6 - failed 
99. Pier comments (eg. undermined penetration, protection and protection extent, unusual scour processes, etc.):

-
-
-
-
-
-
-
-
-

100.

\section{E. Downstream Channel Assessment}

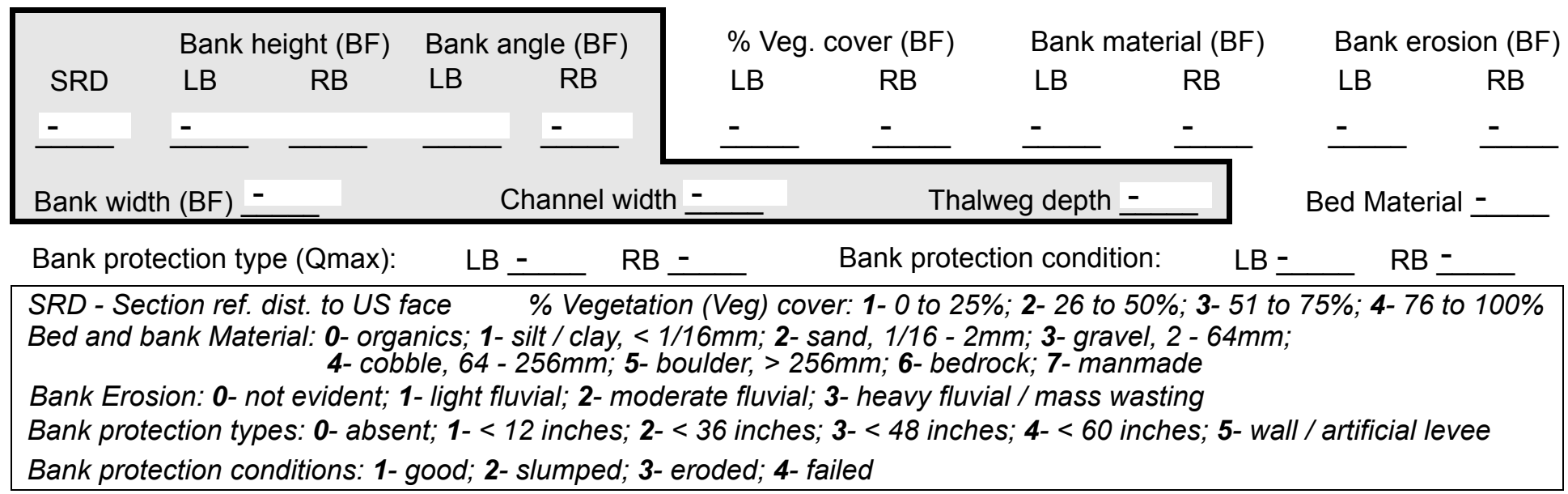

Comments (eg. bank material variation, minor inflows, protection extent, etc.):

$-$

$-$

$-$

$-$

$-$

$-$

$-$

This pier is a timber support (lattice) approximately midway under the bridge.

101. Is a drop structure present? (Y or $N$, if $N$ type ctrl-n ds)

102. Distance: $\mathbf{5 . 5}$ feet
103. Drop: - feet
104. Structure material:
(1- steel sheet pile; 2- wood pile; 3-concrete; 4- other)

105. Drop structure comments (eg. downstream scour depth): 
106. Point/Side bar present? 0 (Y or $N$. if $N$ type ctrl-n pb)Mid-bar distance: $\mathbf{3 4 5}$ Mid-bar width: $\mathbf{0}$

Point bar extent: $\underline{0}$ feet (US, UB, DS) to feet Fro (US, UB, DS) positioned $\underline{\mathbf{m}}$ $\%$ LB to the $\%$ RB

Material: up

Point or side bar comments (Circle Point or Side; note additional bars, material variation, status, etc.):

stream end of the bridge to 63 feet downstream, there is a series of unnatural gravel piles and holes in the channel.

The downstream channel is steeper than the upstream channel.

Is a cut-bank present? (Y or if $N$ type ctrl- $n$ cb) Where? (LB or $R B)$

Mid-bank distance:

Cut bank extent: feet (US, UB, DS) to feet (US, UB, DS)

Bank damage: (1- eroded and/or creep; 2- slip failure; 3- block failure)

Cut bank comments (eg. additional cut banks, protection condition, etc.):

$\mathbf{N}$

Is channel scour present? _-_ (Y or if $N$ type ctrl-n cs) Mid-scour distance: NO

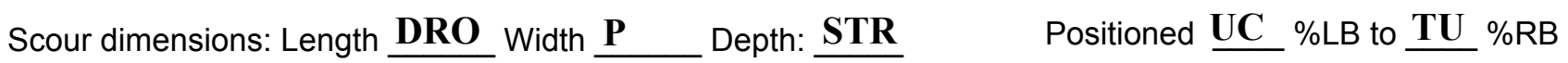
Scour comments (eg. additional scour areas, local scouring process, etc.):

RE

Are there major confluences? ( $Y$ or if $N$ type ctrl-n $m c)$

How many?

Confluence 1: Distance $\underline{\mathbf{Y}}$ Enters on $\mathbf{7 3}$ (LB or $R B)$

Type 22 (1- perennial; 2- ephemeral)

Confluence 2: Distance $\mathbf{5}$ Enters on $\underline{\text { UB }}$ ( $L B$ or RB)

Type 149 (1- perennial; 2- ephemeral)

Confluence comments (eg. confluence name):

DS

20

\section{F. Geomorphic Channel Assessment}

107. Stage of reach evolution $\mathbf{9 5}$

1- Constructed

2- Stable

3- Aggraded

4- Degraded

5- Laterally unstable

6- Vertically and laterally unstable 
108. Evolution comments (Channel evolution not considering bridge effects; See HEC-20, Figure 1 for geomorphic descriptors):

345

Y

LB

26'

0

DS

50

DS

1 


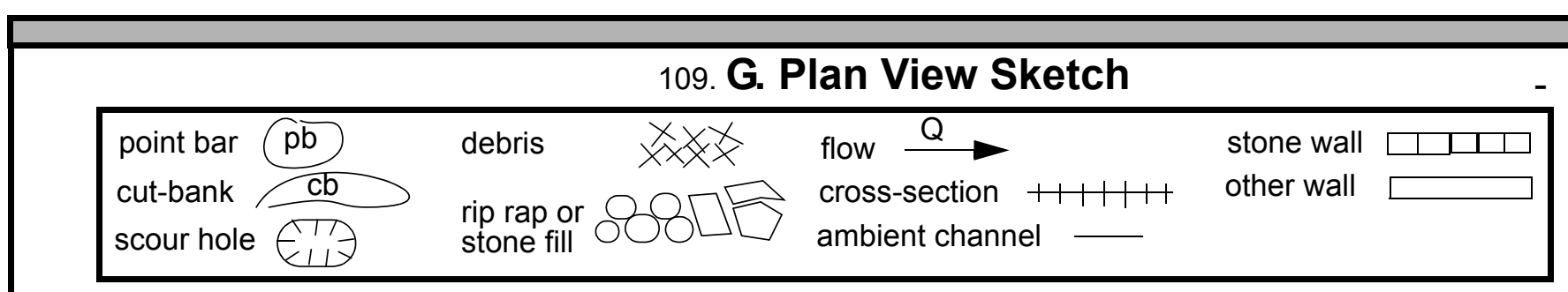


APPENDIX F:

SCOUR COMPUTATIONS 
SCOUR COMPUTATIONS

\begin{tabular}{|c|c|c|c|}
\hline Structure Number: PLYMTH00080037 & & Town : & PLYMOUTH \\
\hline 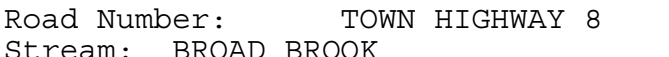 & & County: & WINDSOR \\
\hline Initials ECW & Checked: & RLB & \\
\hline Analysis of contraction scour, live- & -bed or $\mathrm{Cl}$ & lear wat & \\
\hline $\begin{array}{l}\text { Critical Velocity of Bed Material (c } \\
\text { VC=11.21*y1^0.1667*D50^0.33 with Ss= } \\
\text { (Richardson and Davis, 1995, p. 28, }\end{array}$ & $\begin{array}{l}\text { Converted } \\
=2.65 \\
\text { eq. } 16)\end{array}$ & to Eng & sh units) \\
\hline Approach Section & & & \\
\hline Characteristic & $100 \mathrm{yr}$ & $500 \mathrm{yr}$ & other $\mathrm{Q}$ \\
\hline Total discharge, cfs & 1480 & 2200 & 1290 \\
\hline Main Channel Area, ft2 & 267 & 295 & 194 \\
\hline Left overbank area, ft2 & 10 & 18 & 0 \\
\hline Right overbank area, ft2 & 90 & 124 & 12 \\
\hline Top width main channel, ft & 41 & 41 & 41 \\
\hline Top width L overbank, ft & 10 & 13 & 0 \\
\hline Top width $\mathrm{R}$ overbank, ft & 50 & 51 & 27 \\
\hline D50 of channel, ft & 0.287 & 0.287 & 0.287 \\
\hline D50 left overbank, ft & -- & -- & -- \\
\hline D50 right overbank, ft & -- & -- & -- \\
\hline y1, average depth, MC, ft & 6.5 & 7.2 & 4.7 \\
\hline Y1, average depth, LOB, ft & 1.0 & 1.4 & ERR \\
\hline Yl, average depth, ROB, ft & 1.8 & 2.4 & 0.4 \\
\hline Total conveyance, approach & 27947 & 35048 & 14269 \\
\hline Conveyance, main channel & 24063 & 28396 & 14081 \\
\hline Conveyance, LOB & 295 & 607 & 0 \\
\hline Conveyance, ROB & 3589 & 6045 & 185 \\
\hline Percent discrepancy, conveyance & 0.0000 & 0.0000 & 0.0210 \\
\hline Qm, discharge, MC, Cfs & 1274.3 & 1782.4 & 1273.0 \\
\hline Q1, discharge, LOB, Cfs & 15.6 & 38.1 & 0.0 \\
\hline Qr, discharge, ROB, cfs & 190.1 & 379.5 & 16.7 \\
\hline Vm, mean velocity $M C$, ft/s & 4.8 & 6.0 & 6.6 \\
\hline Vl, mean velocity, LOB, ft/s & 1.6 & 2.1 & ERR \\
\hline Vr, mean velocity, ROB, ft/s & 2.1 & 3.1 & 1.4 \\
\hline Vc-m, crit. velocity, MC, ft/s & 10.1 & 10.3 & 9.6 \\
\hline Vc-l, crit. velocity, LOB, ft/s & ERR & ERR & ERR \\
\hline Vc-r, crit. velocity, ROB, ft/s & ERR & ERR & ERR \\
\hline Results & & & \\
\hline Live-bed(1) or Clear-Water(0) Contra & action $\mathrm{ScC}$ & bur? & \\
\hline Main Channel & 0 & 0 & 0 \\
\hline Armoring & & & \\
\hline $\begin{array}{l}\mathrm{DC}=\left[\left(1.94 * \mathrm{~V}^{\wedge} 2\right) /(5.75 * \log (12.27 * \mathrm{Y} / \mathrm{D} 9 \mathrm{C}\right. \\
\text { Depth to Armoring }=3 *(1 / \mathrm{PC}-1)\end{array}$ & ) ) $\left.\wedge^{\wedge} 2\right] /[0$ & $03 *(165$ & $62.4)]$ \\
\hline (Federal Highway Administration, 199 & 93) & & \\
\hline Downstream bridge face property & $100-y r$ & $500-y r$ & Other $\mathrm{Q}$ \\
\hline Q, discharge thru bridge $M C$, cfs & 1314 & $1566^{2}$ & 1290 \\
\hline Main channel area (DS), ft2 & 121 & 154 & 109 \\
\hline Main channel width (normal), ft & 26.1 & 26.1 & 26.0 \\
\hline Cum. width of piers, ft & 1.0 & 1.0 & 1.0 \\
\hline Adj. main channel width, ft & 25.1 & 25.1 & 25.0 \\
\hline D90, ft & 0.7519 & 0.7519 & 0.7519 \\
\hline D95, ft & 1.0958 & 1.0958 & 1.0958 \\
\hline Dc, critical grain size, ft & 0.6255 & 0.4925 & 0.7783 \\
\hline PC, Decimal percent coarser than DC & 0.130 & 0.196 & 0.094 \\
\hline Depth to armoring, ft & 12.56 & 6.06 & $\mathrm{~N} / \mathrm{A}$ \\
\hline
\end{tabular}


Clear Water Contraction Scour in MAIN CHANNEL

\begin{tabular}{|c|c|c|c|}
\hline Bridge Section & Q100 & Q500 & Other \\
\hline (Q) total discharge, cfs & 1480 & 2200 & 1290 \\
\hline (Q) discharge thru bridge, cfs & 1314 & 1566 & 1290 \\
\hline Main channel conveyance & 13302 & 13302 & 7697 \\
\hline Total conveyance & 13302 & 13302 & 7697 \\
\hline Q2, bridge $M C$ discharge, cfs & 1314 & 1566 & 1290 \\
\hline Main channel area, ft2 & 183 & 183 & 109 \\
\hline Main channel width (normal), ft & 26.1 & 26.1 & 26.0 \\
\hline Cum. width of piers in MC, ft & 1.0 & 1.0 & 1.0 \\
\hline $\mathrm{w}$, adjusted width, ft & 25.1 & 25.1 & 25 \\
\hline y bridge (avg. depth at br.), ft & 7.30 & 7.30 & 4.36 \\
\hline $\mathrm{Dm}$, median $(1.25 * \mathrm{D} 50)$, ft & 0.35875 & 0.35875 & 0.35875 \\
\hline $\mathrm{y}^{2}$, depth in contraction, ft & 4.93 & 5.73 & 4.87 \\
\hline ys, scour depth (y2-ybridge), & & -1.56 & 0.51 \\
\hline
\end{tabular}

Pressure Flow Scour (contraction scour for orifice flow conditions)

Chang pressure flow equation $\quad \mathrm{Hb}+\mathrm{Ys}=\mathrm{Cq} * \mathrm{qbr} / \mathrm{Vc}$

$\mathrm{Cq}=1 / \mathrm{Cf} * \mathrm{Cc} \quad \mathrm{Cf}=1.5 * \mathrm{Fr}^{\wedge} 0.43 \quad(<=1) \quad \mathrm{CC}=\mathrm{SQRT}[0.10(\mathrm{Hb} /(\mathrm{ya}-\mathrm{w})-0.56)]+0.79 \quad(<=1)$

Umbrell pressure flow equation

$(\mathrm{Hb}+\mathrm{Ys}) / \mathrm{ya}=1.1021 *[(1-\mathrm{w} / \mathrm{Ya}) *(\mathrm{Va} / \mathrm{Vc})]^{\wedge} 0.6031$

(Richardson and Davis, 1995, p. 144-146)

Q, total, cfs

Q100 Q500 OtherQ

Q, thru bridge $M C$,

$\begin{array}{lll}1480 & 2200 & 1290 \\ 1314 & 1566 & 1290\end{array}$

VC, critical velocity, ft/s

Va, velocity MC approach, ft/s $\quad 4.77 \quad 6.04 \quad 6.56$

Main channel width (normal), ft $26.1 \quad 26.1 \quad 26.0$

Cum. width of piers in MC, ft $1.0 \quad 1.0 \quad 1.0$

W, adjusted width, ft $\quad 25.1 \quad 25.1 \quad 25.0$

qbr, unit discharge, ft2/s $\quad 52.4 \quad 62.4 \quad 51.6$

Area of full opening, ft2

$\mathrm{Hb}$, depth of full opening, ft

Fr, Froude number, bridge MC

Cf, Fr correction factor $(<=1.0)$

**Area at downstream face, ft2

$* * \mathrm{Hb}$, depth at downstream face, ft

**Fr, Froude number at DS face

$* * C f$, for downstream face $(<=1.0)$

Elevation of Low Steel, ft

Elevation of Bed, ft

Elevation of Approach, ft

Friction loss, approach, ft

Elevation of WS immediately US, ft

ya, depth immediately US, ft

Mean elevation of deck, ft

$\begin{array}{lll}183.2 & 183.2 & 109.0\end{array}$

$\begin{array}{lll}7.30 & 7.30 & 4.36\end{array}$

$0.490 .58 \quad 0$

$\begin{array}{lll}1.00 & 1.00 & 0.00\end{array}$

$121 \quad 154 \quad \mathrm{~N} / \mathrm{A}$

$\begin{array}{lll}4.82 & 6.14 & \mathrm{~N} / \mathrm{A}\end{array}$

$0.87 \quad 0.72 \quad$ ERR

$\begin{array}{lll}1.00 & 1.00 \quad \mathrm{~N} / \mathrm{A}\end{array}$

$\begin{array}{lll}498.62 & 498.62 \quad 0\end{array}$

$491.32 \quad 491.32 \quad 0.00$

$\begin{array}{lll}499.7 & 500.38 & 0\end{array}$

$\begin{array}{lll}0.12 & 0.18 & 0\end{array}$

$499.885 \quad 499.885$
0.00

$\begin{array}{llll}\mathrm{w}, \text { depth of overflow, ft }(>=0) & 0.00 & 0.32 & 0.00\end{array}$

6 ERR

$* *$ CC, for downstream face $(<=1.0) \quad 0.8388050 .91513$ ERR

Ys, scour w/Chang equation, ft $\quad-1.96 \quad-0.98 \quad \mathrm{~N} / \mathrm{A}$

Ys, scour w/Umbrell equation, ft $-1.51 \quad-0.35 \quad \mathrm{~N} / \mathrm{A}$

**=for UNsubmerged orifice flow using estimated downstream bridge face properties.

**Ys, scour w/Chang equation, ft $1.36 \quad 0.50 \mathrm{~N} / \mathrm{A}$

**Ys, scour w/Umbrell equation, ft $0.97 \quad 0.81$ ERR

In UNsubmerged orifice flow, an adjusted scour depth using the Laursen equation results and the estimated downstream bridge face properties can also be computed (ys=y2-ybridgeDs)
Y2, from Laursen's equation, ft 4.93
WSEL at downstream face, ft
496.25
5.73
4.87
Depth at downstream face, ft
4.82
497.49
$-0.40$

Ys, depth of scour (Laursen), ft

0.11

$\mathrm{N} / \mathrm{A}$ 
Abutment Scour

Froehlich's Abutment Scour

$\mathrm{Ys} / \mathrm{Y} 1=2.27 * \mathrm{~K} 1 * \mathrm{~K} 2 *\left(\mathrm{a}^{\prime} / \mathrm{Y} 1\right)^{\wedge} 0.43 * \mathrm{Fr} 1 \wedge 0.61+1$

(Richardson and Davis, 1995, p. 48, eq. 28)

Characteristic

Left Abutment

Right Abutment $100 \mathrm{yr} Q 500 \mathrm{yr} Q$ Other Q $100 \mathrm{yr} \mathrm{Q} 500 \mathrm{yr} \mathrm{Q}$ Other Q

(Qt), total discharge, cfs $\begin{array}{llllll}1480 & 2200 & 1290 & 1480 & 2200 & 1290\end{array}$ $\mathrm{a}^{\prime}$, abut.length blocking flow, ft

Qe, discharge blocked abut., cfs

12.6

54

$55.3 \quad 47.8$

(If using Qtotal overbank to obtain

$\begin{array}{llllll}73.57 & 79.11 & 45.01 & 21.69 & 77.31 & 31.96\end{array}$

$\mathrm{Ve},(\mathrm{Qe} / \mathrm{Ae}), \mathrm{ft} / \mathrm{s}$
ya, depth of $\mathrm{f} / \mathrm{p}$

272.63

45.01

$--$

- $\quad 57.74$

ya, depth of $\mathrm{f} / \mathrm{p}$ flow, ft

(eave Qe

lank and enter Ve and Fr manually)

$\begin{array}{lllllll} & 3.62 & 3.40 & 3.57 & 0.40 & 1.40 & 0.67\end{array}$

--Coeff., K1, for abut. type (1.0, verti.; 0.82, verti. w/ wingwall; 0.55, spillthru) $\mathrm{K} 1$
0.82
0.82
0.82
0.82
0.82
0.82

--Angle (theta) of embankment (<90 if abut. points DS; >90 if abut. points US)

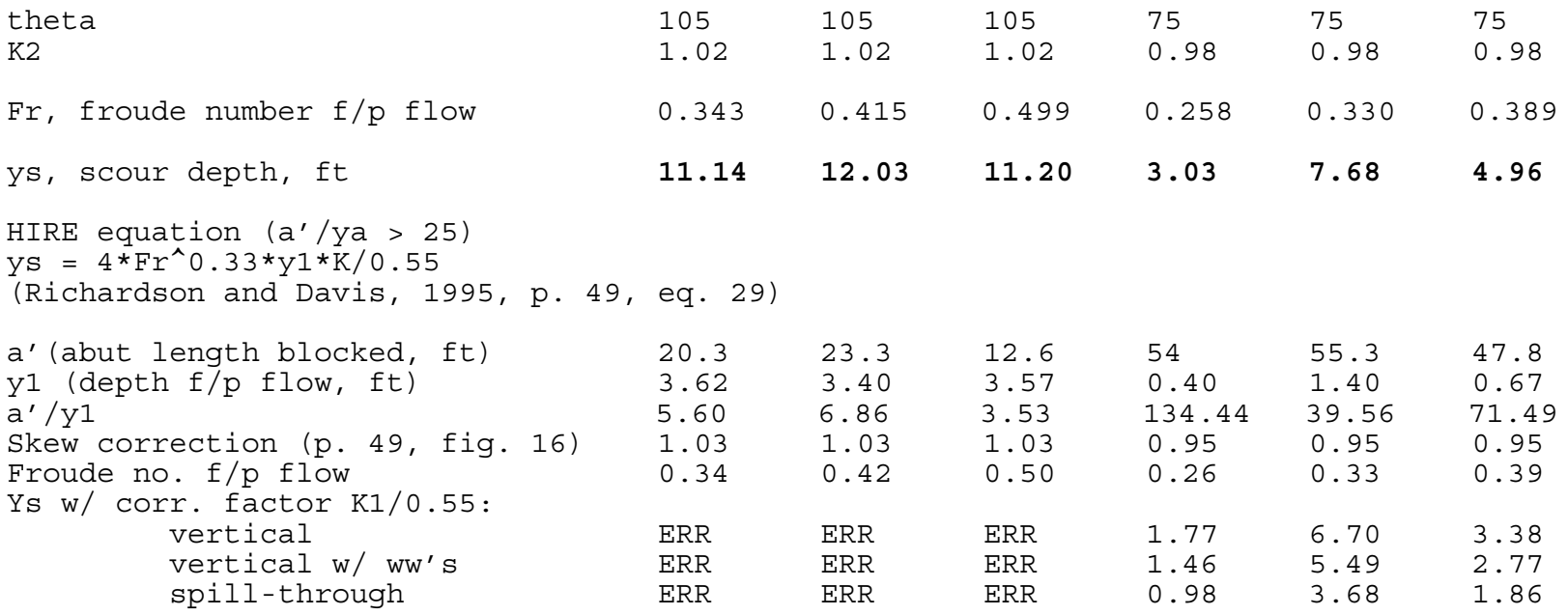

Abutment riprap Sizing

Isbash Relationship

$\mathrm{D} 50=\mathrm{y}^{\star} \mathrm{K} * \mathrm{Fr} \mathrm{r}^{\wedge} 2 /(\mathrm{Ss}-1)$ and $\mathrm{D} 50=\mathrm{y} * \mathrm{~K} *\left(\mathrm{Fr}{ }^{\wedge} 2\right)^{\wedge} 0.14 /(\mathrm{Ss}-1)$

(Richardson and Davis, 1995, p112, eq. 81,82)

\begin{tabular}{|c|c|c|c|c|c|c|}
\hline Characteristic & Q100 & Q500 & Other $Q$ & Q100 & Q500 & Other $Q$ \\
\hline Fr, Froude Number & 0.87 & 0.72 & 0.96 & 0.87 & 0.72 & 0.96 \\
\hline y, depth of flow in bridge, ft & 4.82 & 6.14 & 4.24 & 4.82 & 6.14 & 4.24 \\
\hline $\begin{array}{c}\text { ledian Stone Diameter for ripra } \\
\text { Fr<=0.8 } \\
\text { Fr }>0.8 \quad \text { (vertical abut.) }\end{array}$ & $\begin{array}{l}\text { at: } 1 \text { left } \\
\text { ERR } \\
1.94\end{array}$ & $\begin{array}{l}1.97 \\
\text { ERR }\end{array}$ & $\begin{array}{l}\text { ERR } \\
1.75\end{array}$ & $\begin{array}{l}\text { right } \\
\text { ERR } \\
1.94\end{array}$ & $\begin{array}{l}\text { abutment } \\
1.97 \\
\text { ERR }\end{array}$ & $\begin{array}{l}\text { ft } \\
\qquad \begin{array}{l}\text { ERR } \\
1.75\end{array}\end{array}$ \\
\hline
\end{tabular}


Pier Scour

$\mathrm{Ys} / \mathrm{Y} 1=2.0 * \mathrm{~K} 1 * \mathrm{~K} 2 * \mathrm{~K} 3 * \mathrm{~K} 4 *(\mathrm{a} / \mathrm{Y} 1)^{\wedge} 0.65 * \mathrm{Fr} 1 \wedge 0.43$

(Richardson and Davis, 1995, p. 36, eq. 21)

K1, corr. factor for pier nose shape

Sharp nose, 0.9; round nose, cylinder, or cylinder grp., 1.0; square nose, 1.1

K2, corr. factor attack angle (see Table 3, p 37)

$\mathrm{K} 2=\left[\cos (\text { attackangle })+\mathrm{L} / \mathrm{a}^{*} \sin (\text { attackangle })\right]^{\wedge} 0.65$

K3, corr. factor for bed condition

Clear-water, plane bed, antidune, 1.1; med. dunes, 1.1-1.2 (see Tab.4,p37)

K4, corr. factor for armoring (the following equations are in si units)

$\mathrm{K} 4=\left[1-0.89 *(1-\mathrm{Vr})^{\wedge} 2\right]^{\wedge} 0.5$

$\mathrm{Vr}=(\mathrm{V} 1-\mathrm{Vi}) /(\mathrm{VC} 90-\mathrm{Vi})$

$\mathrm{V} 1=0.645 *((\mathrm{D} 50 / \mathrm{a}) \wedge 0.053) * \mathrm{VC} 50$

$\mathrm{VC}=6.19 *\left(\mathrm{y}^{\wedge} 1 / 6\right) *\left(\mathrm{DC}^{\wedge} 1 / 3\right)$

Note for round nose piers:

ys $<=2.4$ times the pier width (a) for $\mathrm{Fr}<=0.8$

ys $<=3.0$ times the pier width (a) for Fr>0.8

Pier 1

Pier stationing, ft

Area of WSPRO flow tube, ft2

Skewed width of flow tube, ft

y1, pier approach depth, ft

y1 in meters

V1, pier approach velocity, ft/s

a, pier width, ft

$\mathrm{L}$, pier length, ft

Fr1, Froude number at pier

Pier attack angle, degrees

K1, shape factor

K2, attack factor

K3, bed condition factor

D50, ft

D50, m

D90, ft

D90, m

Vc50, critical velocity (D50), m/s

Vc90, critical velocity (D90), m/s

$\mathrm{Vi}$, incipient velocity, $\mathrm{m} / \mathrm{s}$

Vr, velocity ratio

K4, armor factor

ys, scour depth (K4 applicable) ft

Q100 Q500 Qother

$\begin{array}{lll}10.1 & 10.1 & 10.1\end{array}$

$\begin{array}{lll}5.9 & 5.9 & 5\end{array}$

$\begin{array}{lll}0.9 & 0.9 & 0.9\end{array}$

$\begin{array}{lll}6.56 & 6.56 & 5.56\end{array}$

$\begin{array}{lll}1.998 & 1.998 & 1.693\end{array}$

$\begin{array}{lll}11.1 & 13.2 & 12.9\end{array}$

$\begin{array}{lll}1 & 1 & 1\end{array}$

$\begin{array}{lll}6 & 6 & 6\end{array}$

$0.764 \quad 0.909 \quad 0.964$

$\begin{array}{lll}10 & 10 & 10\end{array}$

$1.1 \quad 1.1 \quad 1.1$

$\begin{array}{lll}1.58 & 1.58 & 1.58\end{array}$

$\begin{array}{lll}1.1 & 1.1 & 1.1\end{array}$

$\begin{array}{lll}0.287 & 0.287 & 0.287\end{array}$

$0.087473 \quad 0.087473 \quad 0.087473$

$\begin{array}{lll}0.7519 & 0.7519 & 0.7519\end{array}$

$\begin{array}{llll}0.229168 & 0.229168 & 0.229168\end{array}$

$\begin{array}{lll}3.084 & 3.084 & 3.000\end{array}$

$\begin{array}{lll}4.251 & 4.251 & 4.136\end{array}$

$\begin{array}{lll}1.862 & 1.862 & 1.811\end{array}$

$\begin{array}{lll}0.637 & 0.905 & 0.912\end{array}$

$0.94 \quad 1.00 \quad 1.00$

Pier rip-rap sizing

$\mathrm{D} 50=0.692(\mathrm{~K} * \mathrm{~V}) \wedge 2 /(\mathrm{Ss}-1) * 2 * \mathrm{~g}$

(Richardson and Davis, 1995, p.115, eq. 83)

Pier-shape coefficient (K), round nose, 1.5; square nose, 1.7 Characteristic avg. channel velocity, $\mathrm{V},(\mathrm{Q} / \mathrm{A})$ :

(Mult. by 0.9 for bankward piers in a straight, uniform reach, up to 1.7 for a pier in main current of flow around a bend)

Pier 1

$K$, pier shape coeff.

Q100 Q500 Qother

$\mathrm{V}$, velocity on pier, $\mathrm{ft} / \mathrm{s}$

Used 1.5 to adjust velocity

D50, median stone diameter, ft

$\begin{array}{lll}1.7 & 1.7 & 1.7\end{array}$

$10.335 \quad 12.315 \quad 15$

$2.01 \quad 2.85 \quad 4.23$ 